\title{
Bisphenol A and Type 2 Diabetes Mellitus: A Review of Epidemiologic, Functional, and Early Life Factors
}

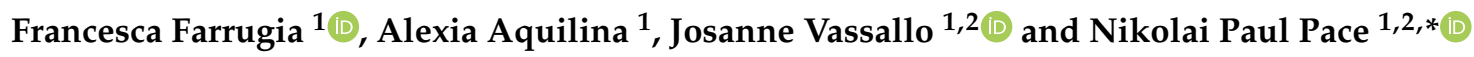 \\ 1 Department of Physiology and Biochemistry, University of Malta, MSD 2080 Msida, Malta; \\ francesca.farrugia.18@um.edu.mt (F.F.); alexia.b.aquilina.18@um.edu.mt (A.A.); \\ josanne.vassallo@um.edu.mt (J.V.) \\ 2 Centre for Molecular Medicine and Biobanking, University of Malta, MSD 2080 Msida, Malt \\ * Correspondence: nikolai.p.pace@um.edu.mt
}

Citation: Farrugia, F.; Aquilina, A.; Vassallo, J.; Pace, N.P. Bisphenol A and Type 2 Diabetes Mellitus: A Review of Epidemiologic, Functional, and Early Life Factors. Int. J. Environ. Res. Public Health 2021, 18, 716. https://doi.org/10.3390/ ijerph18020716

Received: 14 December 2020

Accepted: 13 January 2021

Published: 15 January 2021

Publisher's Note: MDPI stays neutral with regard to jurisdictional claims in published maps and institutional affiliations.

Copyright: (c) 2021 by the authors. Licensee MDPI, Basel, Switzerland. This article is an open access article distributed under the terms and conditions of the Creative Commons Attribution (CC BY) license (https:/ / creativecommons.org/licenses/by/ $4.0 /)$.

\begin{abstract}
Type 2 diabetes mellitus (T2DM) is characterised by insulin resistance and eventual pancreatic $\beta$-cell dysfunction, resulting in persistent high blood glucose levels. Endocrine disrupting chemicals (EDCs) such as bisphenol A (BPA) are currently under scrutiny as they are implicated in the development of metabolic diseases, including T2DM. BPA is a pervasive EDC, being the main constituent of polycarbonate plastics. It can enter the human body by ingestion, through the skin, and cross from mother to offspring via the placenta or breast milk. BPA is a xenoestrogen that alters various aspects of beta cell metabolism via the modulation of oestrogen receptor signalling. In vivo and in vitro models reveal that varying concentrations of BPA disrupt glucose homeostasis and pancreatic $\beta$-cell function by altering gene expression and mitochondrial morphology. BPA also plays a role in the development of insulin resistance and has been linked to long-term adverse metabolic effects following foetal and perinatal exposure. Several epidemiological studies reveal a significant association between BPA and the development of insulin resistance and impaired glucose homeostasis, although conflicting findings driven by multiple confounding factors have been reported. In this review, the main findings of epidemiological and functional studies are summarised and compared, and their respective strengths and limitations are discussed. Further research is essential for understanding the exact mechanism of BPA action in various tissues and the extent of its effects on humans at environmentally relevant doses.
\end{abstract}

Keywords: bisphenol A; type 2 diabetes; beta cell; endocrine disruptors

\section{Introduction}

Type 2 diabetes mellitus (T2DM) is a common chronic metabolic disorder characterised by peripheral insulin resistance, $\beta$-cell dysfunction and an inadequate compensatory insulin secretory response [1]. Persistent hyperglycaemia leads to the development of both microvascular and macrovascular complications, including retinopathy, neuropathy, nephropathy, and an increased incidence of atherosclerotic disease [2,3]. The disorder has an underlying complex aetiology, with several established risk factors including sedentary lifestyle, calorie dense diets, visceral adiposity and a broad array of both common and rare genetic variants [4-6]. In addition to these classical risk factors, an increasing body of evidence implicates environmental chemicals in the rising epidemic of T2DM. Endocrine disrupting chemicals (EDCs) are exogenous chemicals that have adverse metabolic consequences as they interfere with the synthesis, secretion, transport, binding, action and metabolism of endogenous hormones [7,8]. Bisphenol A (BPA) is a widespread EDC that is the main constituent of polycarbonate plastics. It is used in the manufacture of epoxy resins, in the lining of food cans, as well as in recycled paper, carbonless cash register receipts and the coating of CDs and DVDs $[9,10]$. BPA from these products reacts with chlorinated tap water to form chlorinated BPA derivatives [11]. The primary route of human exposure to BPA is oral, and over $90 \%$ of individuals have detectable urine BPA levels even though it is 
a non-persistent EDC with a short half-life [12,13]. Human pharmacokinetic studies indicate that following single exposure by ingestion, BPA undergoes rapid hepatic conjugation and excretion through bile and urine with a half-life of approximately $5.3 \mathrm{~h}$ [14].

BPA is a structural analogue of endogenous $17 \beta$-oestradiol and its precise mechanisms of action at the cellular level are not fully understood. As a xenoestrogen, it binds and acts via extranuclear oestrogen receptors (ER $\alpha$ and $E R \beta)$ at environmentally relevant doses $[15,16]$. ERs are expressed in a wide variety of tissues, including ovaries, testes, prostate, liver, breast, brain, bone marrow, adipose tissue and the pancreas [17]. BPA can act in a cell-type specific manner as an ER agonist at concentrations greater than $10 \mathrm{nM}$, or as an ER antagonist at concentrations less than $10 \mathrm{nM}$ in vitro [18,19]. BPA additionally acts through $G$ protein-coupled receptor 30 (GPR30)—a 7-transmembrane G-protein coupled receptor that mediates the rapid non-genomic signal transduction of oestrogens [20,21]. BPA has relatively high affinity for GPR30, through which it induces the rapid activation of the ERK signalling pathways [14,22]. It has also been shown to inhibit the release of adiponectin, and to exert proangiogenic effects on endothelium [23,24]. Adiponectin has insulin-sensitising, anti-atherogenic and anti-inflammatory properties, and hypoadiponectinemia has been associated with insulin resistance and T2DM [25-28]. BPA also increases the expression of several proinflammatory adipocytokines, including interleukin-6 (Il-6) and monocyte chemoattractant protein $1 \alpha$ (MCP1 $\alpha)$ through GPR30 [29]. Despite the potential mechanistic pathways linking BPA exposure to metabolic disease, several population-based epidemiological studies have shown contradictory or conflicting associations between BPA and T2DM risk. The aim of this article was to (1) provide an updated review of the salient clinical and population studies on BPA and T2DM; (2) review the core mechanistic evidence from functional studies that provides physiologic plausibility to the observed epidemiological associations; (3) relate the association between BPA and T2DM to early life exposure; and (4) outline the emerging mechanisms that could explain the pleiotropic effects of BPA on multiple body systems.

\section{Materials and Methods}

This systematic literature review search is reported in accordance with the Preferred Reporting Items for Systematic Reviews and Meta-Analyses statement guidelines [30]. The article selection process is summarised in a Preferred Reporting Items for Systematic Reviews and Meta-Analyses (PRISMA) flow diagram (Supplementary Figure S1).

\subsection{Study Selection and Inclusion Criteria}

To identify all studies that examine the relationship between BPA and T2DM, we conducted an electronic literature search in PubMed and Medline databases. The search covered articles published between January 2006 and July 2020 and was restricted to articles published in the English language. The following combinations of free text keywords and Medical Subject Heading terms were used in the search: 'Diabetes Mellitus, type 2' (MeSH) AND 'bisphenol A' OR 'BPA'. Epidemiological studies that provided populationlevel measures of association included observational, case-control, cross-sectional studies and meta-analysis. Functional in vivo or in vitro studies that aimed to investigate the mechanistic link between BPA and T2DM were also included. Additionally, studies that reported associations between BPA and metabolic factors that may predispose to T2DM, such as changes in insulin sensitivity, insulin resistance, $\beta$-cell morphology or $\beta$-cell function were also included. Studies investigating critical windows of exposure to BPA were considered valuable as they provide a better understanding of the possible functional consequences of BPA exposure. Furthermore, handsearching and citation review of relevant studies were also conducted to identify studies that were not captured by electronic database search. 


\subsection{Exclusion Criteria}

Studies were excluded if they (1) did not directly assess the relationship between BPA exposure and the development of T2DM or a related metabolic parameter-specifically, articles investigating associations with T1DM and/or gestational diabetes as the primary endpoint were not included. This is because GDM typically describes glucose intolerance diagnosed during gestation that resolves after pregnancy. Key articles on GDM as an early life exposure are discussed separately; (2) articles that were not written in English and (3) reviews, editorial letters, case series or case reports, comments.

\subsection{Data Extraction}

Two investigators independently screened article titles and abstracts and performed study selection and data extraction according to the inclusion and exclusion criteria outlined above. Any discrepancies were adjudicated and resolved by a third independent reviewer. For epidemiological studies, the following information was extracted from the selected articles: (1) primary author and year of publication; (2) type of study; (3) study population characteristics, including cohort size, age, ethnicity and gender proportions; (4) samples used to ascertain BPA levels; and (5) main study outcomes. For animal and in vitro functional studies, the main findings of each article were grouped into sections, depending on (1) the organ or tissue being studied; (2) the window of exposure, namely perinatal or adult exposure; and (3) a detailed description of the cellular mechanism implicated.

\section{Results}

\subsection{Epidemiologic Studies Investigating the Association between BPA Exposure and T2DM}

The literature search yielded 27 key epidemiological studies that assessed the relation between BPA exposure and T2DM. These were selected for full-text review. These studies capture a wide range of heterogeneity with regards to epidemiologic design, sample size, ethnicity, and geographical location, as well as the assay methodology used to ascertain BPA levels. Most studies assayed spot urine BPA using liquid chromatography with tandem mass spectrometry (LC-MS/MS) platforms, although some studies have quantified serum BPA with sandwich enzyme-linked immunosorbent assay (ELISA) methods [31-33]. Free BPA is generally not detectable in blood samples in the general population as following oral ingestion it is rapidly metabolised and eliminated in urine as the glucuronide conjugate [34,35].

\subsubsection{Critical Overview of Epidemiologic Studies}

A systematic summary of these studies and their salient findings is shown in Table 1. Most of the studies selected are characterized by a cross-sectional study design, although case-control cohort and longitudinal studies were also included. Evidence from individual epidemiological studies is generally inconclusive or inconsistent, with conflicting findings being frequently reported. Some studies have reported positive associations for specific subgroups of age or gender [36]. Three meta-analysis have provided pooled estimates of epidemiological data on BPA and T2DM risk [13,37]. These meta-analyses have demonstrated a positive association between increasing BPA levels and insulin resistance or T2DM risk. A summary of the meta-analyses is shown in Table 2.

It is thus unclear whether exposure to BPA is a risk factor for the development of T2DM based on epidemiological examination alone. Several factors might partly account for these conflicting findings. Possible important confounders include the extensive diversity in population ethnicity, lifestyle, dietary intake, use or consumption of BPA-containing products and variation in sample size across investigations. Furthermore, differences in T2DM diagnostic criteria exist between studies. Some studies rely solely on the selfreported diagnosis of diabetes mellitus, while others on an oral glucose tolerance test (OGTT) or HbA1c [38,39].

Additionally, few studies have directly observed a link between BPA and the development of insulin resistance, which is considered a key component in the pathophysiology of 
T2DM. These factors are exacerbated by inconsistency in study end points and considerable uncertainty with regard to the assessment of BPA exposure. The scarcity of prospective studies also limits the direct evaluation of the cause-effect relationship between specific endocrine disruptors and the incidence of diabetes or related metabolic complications, independent of the traditional risk factors [40]. Cross-sectional and case-control studies are not designed to determine causality between BPA and T2DM, and cross-sectional studies are prone to selection bias which could give rise to a heterogeneity of findings $[13,32,41]$.

\subsubsection{BPA Dose-Response Relationship}

BPA concentrations in human blood (serum and plasma) are in the range of 0.3$4.4 \mathrm{ng} / \mathrm{mL}(1.3-19.4 \mathrm{nM})$ in developed countries [42]. The relationship between BPA and metabolic outcomes is complicated by evidence from studies which suggests that it exhibits a non-monotonic dose-response curve. Few substances exhibit such a pattern, and regulatory bodies therefore tend to assume linear relationships when calculating the safe range of doses of a particular substance [43]. Epidemiological studies also assume a linear relationship between BPA exposure and T2DM risk, although this may not reflect the actual dose-response relationship [13]. Most articles discussed in this review report adverse effects at concentrations of BPA that are much lower than the tolerable daily intake proposed by the US Environmental Protection Agency ( $50 \mu \mathrm{g} / \mathrm{kg}-\mathrm{bw} /$ day) and the European Food Safety Authority (4 $\mu \mathrm{g} / \mathrm{kg}-\mathrm{bw} /$ day). This implies that excessively high doses of BPA may not capture the full extent of its effects on the body. Several studies have described adverse effects of BPA at doses below the calculated safe dose $[44,45]$. The non-monotonic dose-response of BPA is likely due to its effects on receptor kinetics and specificity [32,46-49]. Moreover, xenoestrogens such as BPA can act synergistically with endogenous physiological oestrogen, meaning that lower doses of BPA can be sufficient to disrupt certain endocrine features [50]. Given the quantity of evidence that supports a non-monotonic dose-response curve for BPA, further research needs to be performed in order to revise the range of exposure considered to be safe, and to better explain the molecular mechanism underlying such a response.

\subsubsection{Assessing BPA Exposure-Challenges and Caveats}

Pharmacokinetic studies demonstrate that BPA and the related phthalates are rapidly metabolised, and have half-lives of less than $24 \mathrm{~h}$ in the human body [14]. Spot measurements at single time points do not capture chronic exposure to BPA, as evidenced by studies showing a low correlation of serial urinary BPA measurements over 6-month periods $[51,52]$. Thus, the single measurement of urinary BPA in most studies reflects recent BPA exposure and limits its biological interpretation [53]. Assessing BPA levels in a single spot urine sample at the time of T2DM diagnosis is a poor proxy marker of exposure in the years preceding diagnosis. As a weak endocrine disruptor, BPA has the potential to exert deleterious metabolic effects during specific 'exposure windows' in early development, with the consequent onset of metabolic disease in later adulthood. Additionally, urinary BPA levels vary diurnally and can be affected by diuretic therapy [7]. Studies aimed at reducing dietary BPA consumption were not successful at lowering total body BPA levels, suggesting that other sources of exposure exist [11]. The ubiquitous sources of exposure also restrict the ability of investigators to identify study participants that are completely unexposed to environmental BPA.

The long-term effects of short-lived EDCs should be thus evaluated by the incorporation of both baseline and serial assessments of BPA levels in longitudinal studies in relation to metabolic outcomes. Studies have recently applied a time-averaged statistical approach to derive the cumulative average exposure to BPA [54]. To further assess chronic exposure, the health outcomes in occupationally exposed individuals can be compared to environmentally exposed individuals. Selected occupations (BPA/epoxy resin manufacture and thermal paper contact) result in significantly higher BPA levels, and a multitude of 
adverse outcomes, including reproductive and endocrine effects, have been described in occupationally exposed individuals [55].

Large biomonitoring studies have also provided evidence that BPA levels do not decline rapidly with fasting time, suggesting that non-dietary exposure or accumulation in body tissues are relevant in BPA pharmacokinetics [56]. BPA is lipophilic, with a fat: blood coefficient of 3.3 [57]. Additionally, the transdermal and sublingual absorption of BPA that bypasses first-pass metabolism have been documented [58,59]. Clearly, reliance on single spot measurements of urinary BPA provides no evidence of bioaccumulation, due to the potential for the sequestering of EDCs in other body compartments.

A large number of human biomonitoring studies using tissue, blood and urine indicate clearly that the general population is exposed to BPA [12]. BPA is routinely detected in blood in the unconjugated form (nanograms per millilitre range) while conjugated BPA is routinely detected in urine. Unconjugated (parent) BPA is the biologically active EDC. BPA conjugates do not bind nuclear oestrogen receptors, although other biological activities have been attributed to modified BPA [60,61]. The measurement of serum/blood BPA has thus attracted considerable interest in the scientific community. Studies assessing BPA in the serum or blood largely use analytical chemistry methods, although ELISA and radioimmunoassay techniques have been published (reviewed by Vandenburg et al. [12]). Although they are typically smaller in magnitude than urinary BPA studies, most serum or blood BPA studies have reported concentrations of unconjugated BPA in the low $\mathrm{ng} / \mathrm{mL}$ range. Such concentrations are identical to BPA conjugates in urine and indicate internal exposure to biologically active BPA. Importantly, some investigators have failed to detect BPA in blood samples [62,63].

It is essential to emphasise that the measurement of unconjugated BPA in blood has been steeped in controversy. Several issues have been raised that dispute the validity of such measurements, ranging from the contamination of reagents with BPA, the leaching of BPA during sample collection and storage, and the deconjugation of BPA metabolites during sample extraction, thus leading to the erroneous overestimation of free BPA [64,65]. A detailed overview of the controversy concerning unconjugated bioactive BPA in human serum is beyond the scope of this review. However, key industry and FDA-funded studies have rejected biomonitoring data reporting unconjugated BPA in human blood based on post-exposure contamination [66,67]. Conversely, a round-robin study recently showed that the accurate and sensitive quantification of serum unconjugated BPA can be achieved in multiple laboratories, and that BPA contamination is not ubiquitous [68]. Similarly, other authors have disputed universal contamination in serum BPA assays [69].

Notwithstanding this controversy, the direct determination of both total and unconjugated serum BPA can be considered an asset in studies investigating association and causality between BPA and T2DM. More epidemiological studies should endeavour to quantify serum BPA, given its physiological relevance arising from its direct action on nuclear steroid receptors. Urinary BPA levels do not provide meaningful information on internal bioactive concentrations or exposure routes.

The studies summarised in this review article are characterised by considerable variability in the laboratory methodology used to quantify BPA and its reporting. Of note, only some studies specifically report on the use of a comprehensive quality control system to ensure that samples were not contaminated during handling, storage or analysis $[7,40,53,70-73]$. Other studies solely report the limits of detection and within and between day precision metrics $[47,74,75]$. Studies using ELISA employ the use of kits from different manufacturers and report variation in intra and inter-assay precision $[9,32,33]$. It is likely that variability in these analytic parameters limits the direct comparison of epidemiological studies.

\subsubsection{BPA Analogues and Co-Exposure}

In addition to the challenges presented by the short biological half-life of BPA, its rapid first-pass metabolism and possible contamination during sampling or analysis, 
BPA substitutes pose further difficulty. BPA substitutes include structural analogues bisphenol S (BPS) and bisphenol F (BPF) that are increasingly used by manufacturers in BPA-free products. Several key differences between BPA and its substitutes exist. BPS is more stable, less lipophilic and less cytotoxic than BPA [76,77]. Although they have been touted as potentially safer alternatives to BPA, current studies suggest they exert similar endocrine disrupting effects. BPA substitutes possess hormone activity and are increasingly detected in human urine [78-80]. Studies have reported adverse health effects linked to BPA alternatives, and have shown that BPS and BPF have similar potency and action as BPA $[81,82]$. Humans are concurrently exposed to multiple xenobiotics through dietary and environmental sources, and exposure to BPA is thus a likely an indicator of exposure to multiple EDCs. At the population health level, the adverse effects of mixtures of EDCs are more relevant than those of single substances. Recently, Park et al. showed that mixtures of BPA, BPS and BPF exert oestrogen agonist and anti-androgen activities at lower concentrations than single bisphenols [83]. Hence, the mixture effect is a likely confounder variable in epidemiological studies exploring the BPA-T2DM link.

Table 1. Summary of the main findings of the epidemiological studies obtained through the literature search.

\begin{tabular}{|c|c|c|c|}
\hline Reference & Author, Year & Ethnicity & Main Findings \\
\hline \multicolumn{4}{|c|}{ Cross-Sectional Studies } \\
\hline [53] & Lang et al., 2008 & USA & $\begin{array}{l}\text { Higher bisphenol A (BPA) concentrations } \\
\text { were positively correlated with an increased } \\
\text { risk of type } 2 \text { diabetes mellitus (T2DM) and } \\
\text { obesity. Participants in the highest quartile of } \\
\text { BPA level had a greater incidence of T2DM } \\
\text { when compared to the subjects in the } \\
\text { lower quartiles. }\end{array}$ \\
\hline [38] & Ning et al., 2011 & China & $\begin{array}{l}\text { Median urinary BPA levels did not differ } \\
\text { between subjects with normal glucose } \\
\text { regulation, impaired glucose regulation, and } \\
\text { T2DM. There were more younger } \\
\text { participants and males in the highest BPA } \\
\text { quartile. Multivariable analysis did not } \\
\text { reveal a clear association between BPA levels } \\
\text { and T2DM. }\end{array}$ \\
\hline
\end{tabular}

This study was carried out in three National Health and Nutrition Examination Survey (NHANES) cycles in consecutive years. The

[7] Silver, et al., $2011 \quad$ USA analysis of the total sample showed that a 2-fold increase in urinary BPA was associated with T2DM (Odds ratio (OR) 1.08, 95\% C.I.: 1.02-1.16), however this was driven by data from one NHANES cycle.

Urinary BPA levels were higher in females.

[41] Kim and Park, $2013 \quad$ Korea No significant difference in mean urinary BPA concentrations between T2DM and normoglycemic individuals was detected.

[11] Andra et al., $2015 \quad$ USA

The urinary monochlorinated BPA derivative was significantly associated with T2DM, whereas the parent compound (total BPA) was not.

A significantly higher level of BPA in 
Table 1. Cont.

\begin{tabular}{|c|c|c|c|}
\hline Reference & Author, Year & Ethnicity & Main Findings \\
\hline [32] & Soundararajan et al., 2019 & Asian Indians & $\begin{array}{l}\text { Patients with T2DM showed an increased } \\
\text { serum BPA level compared to NGT } \\
\text { participants. Serum BPA levels in female } \\
\text { T2DM patients were significantly higher } \\
\text { compared to their respective control } \\
\text { individuals. This trend was less significant in } \\
\text { males when comparing individuals with } \\
\text { T2DM to NGT participants. There was a } \\
\text { positive correlation between BPA, poor } \\
\text { glycaemic control and insulin resistance. }\end{array}$ \\
\hline
\end{tabular}

[70] Melzer et al., $2010 \quad$ USA associated with coronary heart disease and T2DM in pooled data estimates.

\begin{tabular}{|c|c|c|c|}
\hline [71] & Shankar and Teppala, 2011 & USA & $\begin{array}{l}\text { Urinary BPA levels were found to be } \\
\text { associated with T2DM independently of } \\
\text { traditional diabetes risk factors. }\end{array}$ \\
\hline [84] & Wang et al., 2012 & China & $\begin{array}{l}\text { An elevated concentration of BPA was } \\
\text { positively correlated to an increased } \\
\text { incidence of insulin resistance in adults over } \\
\text { the age of } 40 \text {. This was also accompanied by } \\
\text { an increased tendency of generalised and } \\
\text { abdominal obesity. }\end{array}$ \\
\hline [75] & LaKind et al., 2012 & USA & $\begin{array}{l}\text { No significant correlation was found } \\
\text { between elevated urinary BPA levels and } \\
\text { adverse health outcomes. The authors } \\
\text { suggest that NHANES datasets are not } \\
\text { suitable to draw conclusions between } \\
\text { exposure to chemicals with a short half-life, } \\
\text { such as BPA, and chronic health conditions. }\end{array}$ \\
\hline [73] & Sabanayagam et al., 2013 & USA & $\begin{array}{l}\text { Elevated urinary BPA levels were linked } \\
\text { with prediabetes, after accounting for } \\
\text { confounding variables. Subgroup analysis } \\
\text { revealed that the association was stronger in } \\
\text { females and obese subjects. }\end{array}$ \\
\hline
\end{tabular}

The study could not draw a definitive conclusion on the association between BPA

[85] Casey and Neidell, $2013 \quad$ USA exposure and chronic disease outcomes from NHANES data as results were sensitive to inclusion/exclusion criteria and the statistical model employed.

[33] Aekplakorn et al., $2015 \quad$ Thailand

Serum BPA was independently associated with hypertension in females.

BPA was associated with an increased $\beta$-cell [74] Beydoun et al., 2014 USA $\quad \begin{gathered}\text { function as well as insulin resistance. The } \\ \text { relationship was observed to be stronger }\end{gathered}$ in males.

\section{Case-Control Studies}

[86] Piecha et al., $2016 \quad$ Czech Republic $\quad \begin{gathered}\text { ho association between } \\ \text { hypertension, dyslipidaemia, age and body } \\ \text { mass index (BMI) was reported. }\end{gathered}$


Table 1. Cont.

\begin{tabular}{|c|c|c|c|}
\hline Reference & Author, Year & Ethnicity & Main Findings \\
\hline$[46]$ & Duan et al., 2018 & China & $\begin{array}{l}\text { Elevated urinary BPA concentrations were } \\
\text { associated with an increased risk of T2DM. } \\
\text { The relationship was non-linear as the } \\
\text { association was significant only in the second } \\
\text { and third BPA quartiles but not in the first } \\
\text { (lowest) and fourth (highest) quartiles. }\end{array}$ \\
\hline$[72]$ & Murphy et al. 2019 & Mexico & $\begin{array}{l}\text { Higher free urinary BPA in females with } \\
\text { self-reported diabetes. }\end{array}$ \\
\hline [87] & Li et al., 2018 & Saudi Arabia & $\begin{array}{l}\text { Mean BPA concentration in diabetic } \\
\text { individuals was 3.0-fold higher than in } \\
\text { control participants. The association with } \\
\text { T2DM was strongest in the third } \\
\text { BPA quartile. }\end{array}$ \\
\hline [40] & Ahmadkhaniha et al., 2014 & Iran & $\begin{array}{l}\text { Positive associations were observed between } \\
\text { increasing BPA levels and T2DM in } \\
\text { multi-variable adjusted models. Urinary BPA } \\
\text { concentrations were higher in older } \\
\text { individuals and there was no significant } \\
\text { difference between males and females. }\end{array}$ \\
\hline
\end{tabular}

The administration of a $50 \mu \mathrm{g} / \mathrm{kg} /$ day dose

[49] Stahlhut et al., 2018 USA
of BPA was linked to an altered glucose-stimulated insulin response. Changes in both the early-phase and late-phase insulin responses were detected in response to BPA.

\section{Prospective Studies}

[36] Sun et al., 2014 USA

[47] Watkins et al., 2016

Mexico
BPA levels were associated with incident T2DM in the Nurses' Health Study (NHS) II but not in the NHS I cohort. BPA exposure may be related to the risk of T2DM in middle-aged but not elderly females. The difference between the studies may be attributed to the different age and menopausal status between cohorts.

Urinary BPA is linked to metabolic homeostatic markers during in utero development and peripuberty. In boys, BPA levels were not significantly associated with leptin and C-peptide; however, females showed an $8 \%$ increase in leptin levels. Serum glucose was found to be normal in both sexes.

No significant association between BPA exposure and the risk of incident T2DM was
[88]
Bi et al., 2016
China detected. However, a 34-variant genetic risk score significantly modified the effect of BPA exposure on the longitudinal increase in fasting plasma glucose (FPG). 
Table 1. Cont.

\begin{tabular}{|c|c|c|c|}
\hline Reference & Author, Year & Ethnicity & Main Findings \\
\hline [31] & Shu et al., 2018 & China & $\begin{array}{l}\text { BPA was positively associated with FPG but } \\
\text { not to insulin resistance or } \beta \text {-cell function. } \\
\text { During the follow-up period, baseline BPA } \\
\text { levels could not predict the five-year T2D } \\
\text { incidence. Furthermore, no significant } \\
\text { difference was noted between BPA levels in } \\
\text { healthy participants and in subjects } \\
\text { diagnosed with T2DM. }\end{array}$ \\
\hline [48] & Wang et al., 2019 & China & $\begin{array}{l}\text { BPA was detected in } 89.6 \% \text { of urine samples } \\
\text { with a median concentration of } 0.93 \mathrm{ng} / \mathrm{L} \text {. } \\
\text { There was a } 3.39 \% \text { increase in FPG for every } \\
\text { 10-fold rise in urinary BPA levels. This also } \\
\text { correlated positively with } \beta \text {-cell dysfunction, } \\
\text { fasting hyperglycaemia and higher fasting } \\
\text { insulin levels in females. The association } \\
\text { between BPA and glucose homeostasis } \\
\text { markers was not significant in males. }\end{array}$ \\
\hline [89] & Rancière et al., 2019 & France & $\begin{array}{c}\text { Over a nine-year follow-up, a positive } \\
\text { association between BPA exposure and } \\
\text { incident T2DM was detected independently } \\
\text { of traditional risk factors. }\end{array}$ \\
\hline
\end{tabular}

Table 2. Summary of the main findings of the meta-analyses investigating the association between BPA and T2DM.

\begin{tabular}{|c|c|c|c|}
\hline Reference & Author, Year & Population Size & Main Outcome \\
\hline$[37]$ & Hwang et al., 2018 & 41,320 & $\begin{array}{l}\text { This meta-analysis included a total of } \\
16 \text { epidemiological studies ( } 12 \text { cross-sectional, } \\
2 \text { case-control, } 1 \text { prospective) that focused on } \\
\text { T2DM risk. A positive association between } \\
\text { BPA levels and T2DM risk was described, } \\
\text { with a pooled OR of } 1.28 \text { ( } 95 \% \text { CI } 1.14-1.44) \text {. }\end{array}$ \\
\hline [13] & Song et al., 2016 & 18,077 & $\begin{array}{l}\text { This meta-analysis included a total of } \\
49 \text { epidemiological studies ( } 41 \text { cross-sectional } \\
\text { and } 8 \text { prospective) that explored the } \\
\text { association between multiple endocrine } \\
\text { disrupting chemicals (EDCs) and T2DM. Ten } \\
\text { studies ( } 8 \text { cross-sectional and } 2 \text { prospective } \\
\text { cohorts) investigated BPA. Elevated BPA } \\
\text { levels were related to increased insulin } \\
\text { resistance but not to increased FPG. The } \\
\text { relationship between EDCs and T2DM is } \\
\text { nonlinear. This meta-analysis concluded that } \\
\text { BPA may form part of the environmental } \\
\text { factors contributing to developing T2DM. }\end{array}$ \\
\hline [89] & Rancière et al., 2015 & 9291 & $\begin{array}{c}\text { This meta-analysis included three } \\
\text { cross-sectional studies, all reporting urinary } \\
\text { BPA levels in quartiles. Pooled ORs }(95 \% \mathrm{CI}) \\
\text { for T2DM were } 1.33(1.10-1.61), \\
1.18(0.97-1.44) \text { and } 1.47(1.21-1.80) \text { in the } \\
\text { second, third, and fourth urinary BPA } \\
\text { quartiles respectively, relative to the } \\
\text { first quartile. }\end{array}$ \\
\hline
\end{tabular}




\subsection{BPA Exposure and Early Life Factors}

Major changes in glucose regulation accompany pregnancy, characterised by a degree of insulin resistance, and increased maternal glucose secretion. Commonly, gestational diabetes develops if insulin secretion does not increase sufficiently to counteract the insulin resistance. This can lead to further maternal and foetal metabolic complications, including an increased risk of T2DM in later life [90,91]. The effects of EDCs in pregnancy have been widely studied. Studies have shown that BPA can be passed on from mother to offspring via the placenta and breast milk [12]. Since oestrogen plays an essential role in regulating maternal adaptations to pregnancy, xenoestrogens, such as BPA, are expected to interfere with these processes. In this context, pregnancy and the post-partum state can be considered a critical window of exposure where EDCs can cause significant harmful effects on both mother and foetus.

Pregnant mice exposed to $10 \mu \mathrm{g} / \mathrm{kg} /$ day of BPA throughout gestational days (GD) 916 demonstrated glucose intolerance. A clear dose-response relationship was not described, as the administration of higher quantities of BPA $(100 \mu \mathrm{g} / \mathrm{kg} /$ day $)$ did not lead to a greater degree of glucose intolerance, further hinting at a non-monotonic response. Both BPA doses caused hyperinsulinaemia, whilst $10 \mu \mathrm{g} / \mathrm{kg} /$ day BPA disrupted hepatic insulin signalling and enhanced insulin resistance. While the lower BPA dose resulted in detrimental effects during pregnancy, the higher dosage elicited more deleterious effects post-pregnancy. These include increased post-partum weight gain, hyperinsulinaemia, and elevated levels of plasma leptin, triglycerides and cholesterol [90]. Furthermore, mice developed impaired glucose tolerance and decreased insulin sensitivity at four months postpartum. In contrast, nonpregnant female mice treated with the same doses of BPA did not show any significant changes in glucose tolerance and insulin sensitivity [91]. Importantly, the metabolic changes triggered by BPA in pregnant mice seemed to resolve after delivery but reappeared later in life. This implies that foetal BPA exposure during gestation has long term irreversible effects on the risk of metabolic disorders in later adulthood. Exposure to BPA during gestation also resulted in a significant reduction in maternal glucose-stimulated insulin secretion (GSIS) several months after delivery. BPA exposure triggers changes in the $\beta$-cell life cycle, with increased apoptosis and decreased proliferation leading to a reduced $\beta$-cell mass. These effects are at least partly due to the decreased expression of certain cell cycle activators, such as cyclin D2 (CCND2), and the increased expression of some cell cycle inhibitors, such as cyclin dependent kinase inhibitor $2 \mathrm{~A}(C D K N 2 A)$. Such alterations in the $\beta$-cell mass are thought to arise due to the oestrogen-mimetic effects of BPA [91].

The offspring of mice exposed to BPA during gestation similarly exhibited disordered metabolism. Decreased insulin sensitivity and increased GSIS were detected within 6 months of birth. Of note, males were more adversely affected than females, and lower doses of BPA had more unfavourable effects than the higher dose. It is likely that female offspring are less affected than males as oestrogens within the physiological range may protect against diabetes. These metabolic alterations in the offspring of mice exposed to BPA during gestation result in a higher risk of developing T2DM and associated disorders later in life [90]. Similarly, Manukyan et al. showed that gestational exposure to very low doses of BPA via the oral route leads to insulin hypersecretion in rat offspring up to one year after exposure. They demonstrated that at lower doses of BPA, GSIS was enhanced in pancreas from both 5- and 52-week-old offspring. Contrastingly, at higher doses of BPA a reduced GSIS was observed. These findings further emphasise the long-lasting effects of BPA, even after exposure is terminated. The pattern of insulin secretion induced by higher BPA doses is quite similar to that observed in diabetic patients, where first-phase insulin secretion was reduced. Additionally, the lower dose of BPA could also be detrimental as the prolonged hypersecretion of insulin may cause added stress to the $\beta$-cell [92].

Since obesity is a major risk factor for T2DM, measurements of weight gain and fat distribution in early life can be predictive of possible metabolic complications in later life. Wei et al. observed the aftermath of perinatal BPA exposure on offspring fed either a standard diet or an high-fat diet (HFD). The offspring of dams exposed to BPA exhibited 
higher weight gain and larger adipocytes at 19 weeks of age compared to controls, an effect that was exacerbated by HFD. Male mice demonstrated greater disruptions in serum lipid levels than females, primarily featuring higher triglyceride and lower HDL cholesterol levels. Moreover, fasting blood glucose and insulin levels were increased by week nine, and this was accompanied by islet changes-including enlarged and scattered $\beta$-cells in the HFD group. In addition, several transcription factors were downregulated. Of note, the standard diet group and HFD females showed higher GSIS, while HFD males showed lower GSIS. These findings indicate the faulty development of $\beta$-cells early on in life, which is aggravated by an HFD. Surprisingly, very high doses of BPA (250 and $1250 \mu \mathrm{g} / \mathrm{kg}-\mathrm{bw} /$ day) did not induce any significant changes [93].

Evidence from epidemiological studies suggests that low birth weight leads to rapid post-weaning weight gain, a phenomenon termed "centile crossing". This is a possible risk factor for the subsequent development of obesity and T2DM. A study by Taylor et al. demonstrated this effect in newborn male mice. The authors showed that mice with the highest post-weaning weight gain exhibited the greatest elevation of blood glucose after a low-dose glucose tolerance test. Furthermore, perinatal BPA exposure impacts on body weight at weaning as well as the rate of post-weaning growth. The findings from this study suggest that foetal exposure to low-dose BPA is more likely to affect a sensitive subpopulation characterised by early life growth restriction and rapid catchup growth post weaning, which could be at higher risk for the development of T2DM [94].

Other studies have shown that the metabolic outcomes of BPA differ according to the timing of the exposure window, as well as dosage and gender. Liu et al. show that mice exposed to BPA during the postnatal period showed the highest weight gain, while those exposed in early pregnancy weighed less than controls [95]. $\beta$-cells are susceptible to the effects of BPA in both the foetal and neonatal periods, resulting in increased $\beta$ cell mass with reduced or invariable insulin secretion. Similar detrimental effects of BPA exposure were observed in larger mammals such as sheep. The offspring of sheep exposed to BPA during gestation demonstrate pre-pubertal hyperglycaemia and insulin resistance, an identical phenotype to T2DM. This prepubertal insulin resistance sets the stage for further disruption in glucose and insulin regulation after puberty [96], as was observed in mice from studies discussed earlier [90,91]. Furthermore, sheep exposed to BPA demonstrate a higher visceral to subcutaneous adipose tissue ratio and increased CD68 expression, a marker of inflammation indicative of macrophage infiltration in adipose tissue [96].

Several investigators have investigated birth outcomes following BPA exposure. The Korean Mothers and Children's Environmental Health (MOCEH) study revealed significant positive associations between maternal BPA exposure and higher birth weight, which were stronger in male neonates [97]. A recent meta-analysis of seven independent studies showed a similar direction of association between BPA and higher birth weight [98]. Prenatal BPA exposure has also been linked with sex-specific changes in hypothalamicpituitary-adrenal axis function, and the epigenome-wide methylation analysis of cord blood DNA similarly identified sex-specific effects $[99,100]$. Importantly, a prospective study showed that prenatal BPA exposure has residual sex-specific effects on glucose and lipid metabolism that persist into childhood, although maternal bisphenol exposure was not associated with childhood adiposity [101,102]. Bansal et al. also showed that maternal BPA exposure exerts gender-specific multigenerational effects, impairing insulin secretion in male but not female mice through epigenetic changes involving insulin-like growth factor 2 (IGF2) - a key $\beta$-cell gene [103]. Sexual dimorphic effects of prenatal BPA exposure on hepatic gene expression, body composition and glucose homeostasis in murine and rat models have been reported [104,105]. These findings further support the role of ER-dependent mechanisms in mediating gender-specific metabolic effects.

In summary, the foetal and neonatal periods constitute key critical intervals for BPA exposure. An overview of the adverse metabolic effects of BPA at these life stages is shown in Figure 1. The ongoing pancreatic development can result in the programming of metabolic 
outcomes that lead to insulin resistance and the development of glucose intolerance in adult life. Different window of BPA exposure can thus have varying effects that depend, in part, on the offspring's developmental stage at exposure. Further research is required to uncover the precise mechanism by which BPA disrupts the delicate programming of this part of the endocrine system [95].

Maternal effects of BPA exposure during pregnancy

- Glucose intolerance

-Hyperinsulinaemia

-Insulin resistance

-Effects observed with relatively low dose exposure to BPA

\section{Effects on newborn exposed to BPA perinatally}

- Greater weight gain and larger adipocytes (exacerbated by HFD)

- Higher TG and lower HDL-C levels in males -Increase in FPG and insulin levels if fed HFD

-Increase in FPG and insulin levels and $\beta$-cell size

-Impaired development of $\beta$-cells in early life

(aggravated by HFD)

- Lower BPA doses had a more profound effect

-Sex-specific changes in HPA axis

\author{
Effects on newborn exposed to BPA during \\ gestation \\ -Increased insulin sensitivity \\ -Insulin hypersecretion \\ - Higher birth weight \\ -Males more adversely affected than females \\ - Lower BPA doses had a more profound effect
}

Consequences for offspring in adulthood

-Increased risk of developing T2DM (or related

metabolic disorders) in adulthood, particularly in

offspring with low birth weight and which undergo

rapid post-weaning weight gain

-Higher visceral to subcutaneous adipose tissue ratio

Figure 1. Overview of the adverse metabolic effects of BPA at the foetal, neonatal, and adult stages. HFD—high fat diet. TG—-triglycerides. HDL-C—high density lipoprotein cholesterol.

\subsection{BPA and T2DM-From Epidemiological Associations to Mechanistic Evidence}

Several in vitro and in vivo animal studies have attempted to unravel the mechanistic link between BPA and T2DM. The findings from key functional studies are outlined next.

\subsubsection{Effect of BPA on Glycaemia, Insulin Resistance and Lipids}

As BPA is a phenolic xenoestrogen pollutant, it imitates the effects of endogenous oestrogen $\left(\mathrm{E}_{2}\right)$. Multiple studies have shown that both BPA and $\mathrm{E}_{2}$ induce a rapid dosedependent change in glycaemic response and insulinaemia in adult mice [16,106,107]. Alonso-Magdalena et al. demonstrated that acute exposure to a single low dose of either $\mathrm{BPA}$ or $\mathrm{E}_{2}$ produces a rapid decrease in the rise of glycaemia within $30 \mathrm{~min}$ of the first injection. This is the result of an increase in plasma insulin. Furthermore, sustained exposure to either BPA or $E_{2}$ at 10 and $100 \mu \mathrm{g} / \mathrm{kg} /$ day resulted in higher $\beta$-cell insulin levels, an effect mediated through the oestrogen receptor. Exposure to the higher BPA dose resulted in hyperinsulinemia, with plasma insulin levels comparable to those in late pregnancy. Both the $E_{2}$ and the BPA-treated mice exhibited 1.7- and 1.53-fold higher circulating insulin levels, respectively, with unvarying blood glucose levels. This is characteristic of insulin resistance [107]. The hyperinsulinaemic effect of BPA was also demonstrated by murine studies showing that eight days of BPA exposure resulted in an increase in GSIS and inhibition of basal insulin secretion. The effects of BPA on glycaemia and GSIS were completely abolished in islets from $\mathrm{ER} \alpha$ knockout mice but not in $\mathrm{ER} \beta$ knockout mice, suggesting that BPA upregulates pancreatic insulin content through a mechanism involving the activation 
of $E R \alpha$ [15]. Taken together, these findings provide strong support for a direct link between BPA, $\beta$-cell function and insulin resistance $[15,108,109]$.

Ding et al. investigated the effects of long-term exposure to a dose ( $50 \mu \mathrm{g} / \mathrm{kg} / \mathrm{day})$ of BPA and its interaction with high-fat diet. They reported that serum glucose levels were significantly higher in BPA-treated male rats than the untreated controls following 35 weeks of BPA exposure. BPA treatment in combination with a high-fat diet (HFD) resulted in a higher elevation of serum glucose levels than a HFD alone. The study also showed that BPA-treated rats on a standard diet had an increase in serum insulin levels, an elevated homeostatic model assessment of insulin resistance (HOMA-IR) and a reduced insulin sensitivity index (ISI) compared with the control group. The persistent hyperglycaemia, despite higher circulating insulin levels elicited by BPA, is an indicator of insulin resistance and disrupted glucose homeostasis [110].

In a similar study, Marmugi et al. administered increasing doses of BPA to six-weekold male mice for 32 weeks via drinking water. Following long-term exposure, a dosedependent elevation of plasma glucose levels was observed. Moreover, the mice exposed to the highest dose showed significantly impaired glucose tolerance when compared to the control group. In contrast with the previously mentioned studies, this study did not observe a significant difference between the plasma insulin levels of BPA-treated mice and the control group [111]. Similarly, Moon et al. reported that the 12-week exposure to $50 \mu \mathrm{g} / \mathrm{kg} /$ day of BPA via the oral route to mice on HFD resulted in glucose intolerance and insulin resistance. In keeping with Marmugi et al., no statistically significant increase in fasting serum insulin levels between the BPA-treated group and the control group was detected [112].

An HFD increases serum triglycerides and total cholesterol levels when compared with the standard diet; however, no significant difference in lipid profiles was observed between the BPA-treated groups and the untreated groups [110]. Conversely, Marmugi et al. demonstrated an increase in total cholesterol levels in mice exposed to BPA. This effect is mediated by the upregulation of hepatic genes involved in de novo cholesterol biosynthesis [111].

\subsubsection{Effect of BPA on $\beta$-Cell Mass, Morphology and Function}

When compared to the other phenolic oestrogen pollutants such as diethylstilbestrol, octylphenol and nonylphenol, BPA has a lower oestrogenic activity [113]. In rat insulinoma cell lines, $48 \mathrm{~h}$ exposure to BPA decreases cell viability, disrupts GSIS and triggers apoptosis in a dose-dependent manner [114]. BPA activates $\beta$-cell apoptotic signalling via the increased expression of pro-apoptotic Bax protein and the reduced expression of anti-apoptotic Bcl-2. Structural defects in rat $\beta$-cell mitochondria that precede changes in glucose homeostasis have been documented following the administration of $50 \mu \mathrm{g} / \mathrm{kg} /$ day of BPA [93]. Using rat islet cells, Song et al. showed that at a dose of $2.5 \mu \mathrm{g} / \mathrm{L}$, BPA reduces $\beta$-cell viability, whereas an identical effect was observed with much higher doses of the other oestrogenic pollutants. This is of interest as $2.5 \mu \mathrm{g} / \mathrm{L}$ is within the range of human exposure to BPA. BPA affects the insulin-secreting ability and mass of isolated islets. $\beta$-cell diameter increases at BPA doses between 2.5 and $25 \mu \mathrm{g} / \mathrm{L}$ but decreases at a dose of $250 \mu \mathrm{g} / \mathrm{L}$, possibly due to cytotoxic effects on the $\beta$-cells at a high dose. Transmission electron microscopy (TEM) studies revealed that $25 \mu \mathrm{g} / \mathrm{L}$ of BPA results in a reduced amount of filled insulin vesicles and an increase in empty vesicles [115]. Similarly, prolonged BPA exposure causes an increase in $\beta$-cell mass due to islet expansion, an effect that is aggravated by HFD [110]. Conflicting findings have also been described. Moon et al. reported no change in the islet morphology in mice exposed to both BPA and HFD when compared to mice given a HFD only. Electron microscopy showed no difference in the number and shape of mitochondria, as well as the insulin content of the cells [112]. The heterogeneity of findings can be partly accounted for by differences in rodent species, their age, duration, route, and level of exposure. 
As many EDCs follow a non-monotonic dose-response curve, the most effective dose of EDC may not necessarily be the highest one. Instead, the focus is being directed towards the dose that has maximal adverse effects on a specific metabolic pathway [111]. An inverted U-shaped relationship exists between incremental doses of BPA and GSIS. A dose of $0.1 \mu \mathrm{g} / \mathrm{L}$ of BPA was enough to cause a significant increase in GSIS, whilst doses of 25 and $250 \mu \mathrm{g} / \mathrm{L}$ caused a significant decrease [115]. Lower doses of BPA, mainly $0.1 \mu \mathrm{g} / \mathrm{L}$ and $1 \mu \mathrm{g} / \mathrm{L}$, have also been shown to increase both basal and GSIS [116]. As GSIS depends on signals generated by $\beta$-cell mitochondria, any mitochondrial abnormality could be a potential contributor to metabolic disorders such as T2DM [117]. Song et al. showed that BPA and other phenolic oestrogens induce ultrastructural changes in $\beta$-cells. Specifically, $\beta$-cell mitochondrial swelling with a loss of structural integrity, impaired mitochondrial cytochrome c oxidase function and reduced cytosolic ATP levels were observed in BPAtreated islets [115].

Alternative mechanisms linking BPA to $\beta$-cell apoptosis and a decrease in $\beta$-cell mass have been described. BPA is implicated in $\beta$-cell damage through its interaction with human islet amyloid polypeptide (hIAPP). hIAPP is a 37-residue soluble polypeptide that is produced by the $\beta$-cell and is co-secreted with insulin. The function of hIAPP in the $\beta$-cell is not fully understood, and distinguishing physiological from pathological effects is a considerable challenge [118]. Physiologically, it contributes to glycaemic regulation by inhibiting insulin and glucagon secretion, inhibiting gastric emptying, as well as acting centrally to induce satiety [118-120]. hIAPP monomers also possess intrinsic propensity to misfold, forming $\beta$-sheet oligomers that assemble into linear fibrils. The oligomers and fibrils exert cytotoxic effects on pancreatic $\beta$-cells by inducing membrane permeabilisation and disruption [121,122]. The link between hIAPP and T2DM has been well established by studies demonstrating that IAPP aggregates are detectable in most diabetics and a spatial correlation exists between IAPP deposits and loss of $\beta$-cell mass [118,121,123]. Aggregates of IAPP insert into the $\beta$-cell membrane, causing the leakage of cellular contents and eventually apoptosis. Critically, in vitro studies using a rat insulinoma cell line demonstrated that BPA acts in a dose-dependent manner to promote hIAPP aggregation and membrane disruption [124]. As the cell membrane becomes more permeable, $\mathrm{Ca}^{2+}$ ions enter the cell and trigger the generation of harmful reactive oxygen species (ROS). This process was observed in the presence of BPA and hIAPP, but not with BPA alone, hence suggesting the possible cooperative action of the two molecules [124]. This study by Gong et al. thus showed that BPA can contribute to T2DM development through the modulation of $\beta$-cell survival. The highly fibrillogenic hIAPP is normally protected from aggregation by its interaction with inhibitors of fibril formation, such as insulin and zinc ions [125]. Some authors have hypothesised that the formation of IAPP aggregates plays a critical role in the transition from early-stage insulin resistance to overt T2DM. The compensatory hyperinsulinemia arising due to insulin resistance leads to a higher production of hIAPP and increases endoplasmic reticulum stress, which exacerbates $\beta$-cell demise, in turn leading to greater insulin/IAPP production in the surviving $\beta$-cells [126,127]. The mechanisms inducing the formation of cytotoxic hIAPP aggregates in pancreatic $\beta$-cells, their role in the development and progression of T2DM, and the significance of BPA in this process is, however, not fully resolved.

\subsubsection{Effect of BPA on $\beta$-Cell Gene Expression}

The effect of BPA on $\beta$-cell function and impaired insulin secretion is a consequence of dysregulated $\beta$-cell gene expression. Twenty-four-hour exposure to $25 \mu \mathrm{g} / \mathrm{L}$ BPA results in a downregulation of the pancreatic glucose transporter (SLC2A2) and glucokinase $(G C K)$, and consequently reduced insulin secretion. Glucokinase is an enzyme involved in the first step of glycolysis, as it catalyses the phosphorylation of glucose to glucose-6phosphate. The decreased expression of GCK and SLC2A2 is the result of downregulation of key $\beta$-cell genes, including insulin promoter factor 1 (PDX1), and hepatocyte nuclear factor 1A (HNF1A). The synaptosome-associated protein of $25 \mathrm{kDa}$ (SNAP25) expression 
is also decreased in response to BPA. This gene functions in vesicle fusion to plasma cell membranes during exocytosis [115].

Chronic BPA exposure, in isolation or in combination with HFD, elicits cellular stress responses. The upregulation of genes in cellular autophagy pathways, such as microtubule associated protein 1 light chain 3 alpha $(M A P 1 L C 3 A)$ and beclin 1 (BECN1) has been documented in response to BPA [110]. Similarly, BPA exposure triggers the altered expression of genes encoding molecular chaperone proteins, such as the heat shock protein 90 beta family member 1 (HSP90B1) and heat shock protein family A (Hsp70) member 5 (HSPA5). The observed transcriptomic changes are dependent on the prevailing glucose concentration, the duration and concentration of BPA exposure and thus requires further evaluation [116].

\subsubsection{Cellular Mechanisms of BPA Action}

Recent studies have highlighted the role of BPA in modulating the expression and function of $\beta$-cell ion channels that regulate GSIS [128]. In the fasting state, the consumption of ATP by cellular metabolic pathways results in low ATP:ADP ratio, an increased activity of ATP-sensitive $\mathrm{K}^{+}$channels and hyperpolarised $\beta$-cell membrane potentials. Following glucose uptake by $\beta$-cells in the postprandial state, the rise in ATP:ADP ratio results in the generation of an oscillatory current that alternates between hyperpolarised and depolarised phases. The depolarisation phase is mediated by the activation of voltage-activated $\mathrm{Ca}^{2+}$ and $\mathrm{Na}^{+}$channels and leads to bursts of action potentials, while the repolarisation phase is mediated by the activation of small-conductance $\mathrm{Ca}^{2+}$-activated $\mathrm{K}^{+}$channels $\left(\mathrm{K}_{\mathrm{Ca}} 2.3\right.$ channels). The alternating depolarisation and hyperpolarisation phases cause an oscillatory release of $\mathrm{Ca}^{2+}$, which in turn, stimulates the exocytosis of insulin-containing vesicles from the $\beta$-cell $[16,128]$.

Martinez-Pinna et al. showed that the exposure of murine $\beta$-cells to BPA results an imbalance in their electrical activity. Electrophysiological studies on islets from mice exposed to BPA demonstrate a decrease in $\mathrm{Na}^{+}$and $\mathrm{K}^{+}$currents. Microarray gene expression analysis identified the dysregulation of several genes encoding components of $\mathrm{Na}^{+}$and $\mathrm{K}^{+}$channels, including sodium voltage-gated channel alpha subunit 9 (SCN9A), potassium voltage-gated channel subfamily B member 2 (KCNB2), potassium calcium-activated channel subfamily $\mathrm{M}$ alpha 1 (KCNMA1) and potassium voltage-gated channel interacting protein 1 (KCNIP1). These effects were not observed in $\beta$-cells from oestrogen receptor $\beta$ knockout mice $\left(E R \beta^{-/-}\right)$, suggesting that the modulation of $\mathrm{Na}^{+}$and $\mathrm{K}^{+}$currents by BPA are mediated by ER $\beta$ [128]. Importantly, the concentration of BPA used in this experiment is identical to that in human serum, and changes in the expression or activity of beta cell ion channels are implicated in T2DM [129]. Such changes in $\beta$-cell electrical activity may contribute to impaired insulin secretion and the diabetogenic effects of BPA [128]. Conversely, in human studies, oral BPA supresses second-phase GSIS in obese individuals [49]. Possibly, BPA has differing effects on the mechanisms of the early response (release of stored insulin) vs. later insulin response (de novo insulin synthesis). Other murine studies have supported this concept, showing that the effects of BPA on insulin exocytosis and secretion vary according to the absence or presence of glucose and its concentration, and are mediated by both ER $\beta$ and $E R \alpha$ [130].

Soriano et al. further demonstrated the role of ER $\beta$ in the regulation of the $\mathrm{K}_{\mathrm{ATP}}$ channel activity, $\mathrm{Ca}^{2+}$ flow and insulin release elicited by environmentally relevant doses of BPA. BPA reduced $\mathrm{K}_{\mathrm{ATP}}$ channel activity by almost half in islets from both mice and humans and increased the frequency of pulsatile $\mathrm{Ca}^{2+}$ release and insulin secretion. These effects were absent in ER $\beta^{-/-}$mice, confirming that BPA acts through ER $\beta$ to induce changes related to insulin secretion. It is possible that BPA can act in this manner in humans as the concentration of BPA in serum is identical to the dose used in this study. Further research is required to fully understand the involvement of other oestrogen receptors in $\beta$-cells, as these may act in a non-classical manner when bound to BPA. In addition to animal models, 
more human $\beta$-cell studies are needed to account for any differences between rodent and human physiology [16].

\subsubsection{Effect of BPA on Other Tissues}

Exposure to BPA in animal studies has been shown to induce significant alterations in whole body metabolism and feeding patterns. Animal studies have described sex-specific alterations in hypothalamic pathways controlling the energy intake and expenditure induced by BPA [131]. Reduced proopiomelanocortin expression, increased leptin and neuropeptide $Y$ levels in the arcuate nucleus have been reported, suggesting that BPA induces the dysregulation of the melanocortin system that regulates energy balance [132]. Furthermore, when compared to controls, BPA-treated mice exhibited unchanged diurnal but reduced nocturnal food intake, a decrease in spontaneous locomotor activity and a decrease in overall energy expenditure. Potentially, these effects are accounted for by the oestrogenic properties of BPA that allow it to act on the central nervous system to induce changes in leptin and insulin levels [108].

Skeletal muscle carries a high metabolic demand and is a major insulin-sensitive tissue. It therefore plays a critical role in blood glucose homeostasis. Insulin-signalling pathways in muscle can also be altered by exposure to environmentally-relevant doses of BPA [108]. Insulin receptor substrate 1 (IRS1) is essential for various processes, including insulin receptor signalling, the growth of myofibers, insulin-dependent glucose uptake and glycogen synthesis [133]. Exposure to BPA results in the upregulation of IRS1 in skeletal muscle. In BPA-treated mice, the insulin-stimulated phosphorylation of the insulin receptor $\beta$ subunit is impaired, resulting in a reduction in insulin-induced Akt phosphorylation. These alterations in insulin receptor signalling pathways in response to short-term exposure to low doses of BPA provide insight into the development of peripheral insulin resistance, a key hallmark of T2DM [108]. Of note, similar observations in Akt phosphorylation were recorded in studies using muscle cells from T2DM patients [134].

In hepatocytes, BPA elicits identical perturbations in insulin signalling pathways to those observed in skeletal muscle [108]. In the liver, IRS1 participates in the regulation of lipid and glucose metabolism, and this protein is upregulated by exposure to BPA under basal conditions [133]. Evidence also points to the disruption of hepatic glucose regulation by BPA. Acute (single dose) and chronic (over 2 weeks) BPA exposure results in a significant reduction in glucokinase activity under several physiological glucose concentrations. While oestrogen stimulates glucokinase activity, BPA treatment reduces it under these conditions [135]. Conversely, $500 \mu \mathrm{g} / \mathrm{kg} /$ day BPA exposure over eight months lead to an increase in glucokinase and pyruvate kinase enzymes. BPA also induces oxidative stress in hepatocytes by reducing the activities of antioxidant enzyme superoxide dismutase, glutathione peroxidase and catalase [136]. Furthermore, animal studies have shown that BPA exposure is linked to changes in liver activity, hepatocyte DNA damage and the induction of hepatocyte apoptosis [137-139]. In the liver, BPA stimulates lipid accumulation through the upregulation of lipogenic genes, such as sterol regulatory element binding protein 1 (SREBP1) [140,141]. This evidence suggests that BPA contributes to the development of non-alcoholic fatty liver disease (NAFLD), a frequent metabolic disturbance in T2DM [142,143].

In addition, the sustained exposure of adult mice to BPA over a period of eight months results in the significant upregulation of genes involved in de novo lipogenesis. These include $F A S N$ - the gene encoding fatty acid synthase, a principal enzyme functioning in the de novo synthesis of long-chain fatty acids, as well as thyroid hormone responsive protein (THRSP), syndecan 1 (SDC1), patatin like phospholipase domain containing 3 (PNPLA3) and sterol regulatory element binding transcription factor 1 (SREBF1). Moreover, such long-term BPA exposure leads to an increase in the key enzymes of de novo cholesterol biosynthesis, including 3-hydroxy-3-methyl-glutaryl-coenzyme A reductase (HMG-CoA reductase). Increased hepatic cholesterol levels have been reported in mice exposed to BPA, with no significant change in the levels of hepatic triglycerides and cholesteryl esters [111]. 
The expression of these genes is also increased by hyperinsulinemia, and the observed metabolic deregulation is also consistent with evidence from early-life exposure animal studies. Conversely, it contrasts with the proposed reduction in insulin secretion suggested by some studies, although this is explained by the differing effects of BPA on early and late phases of insulin secretion. A summary of the general metabolic effects of BPA is illustrated by Figure 2. 


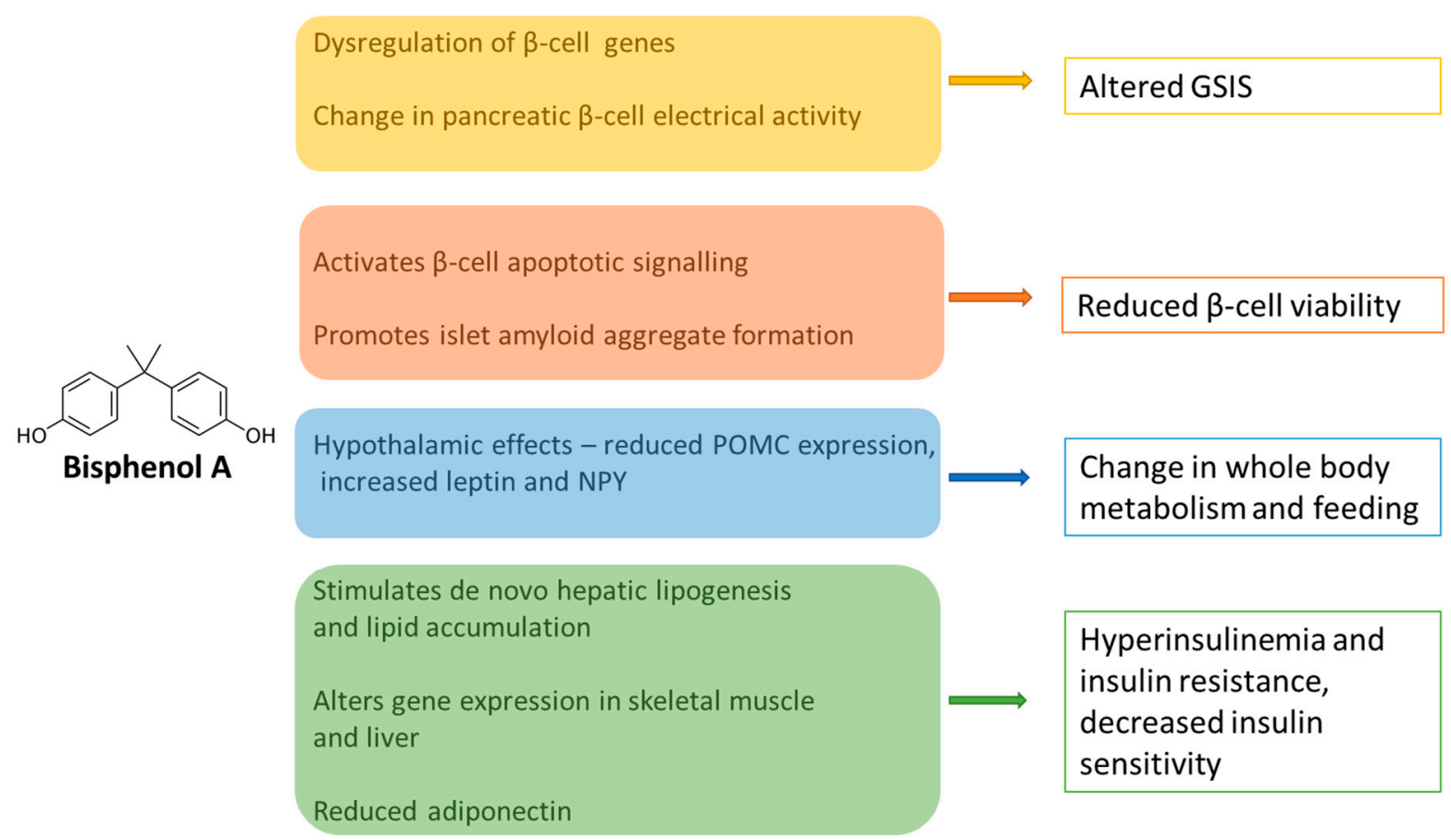

Figure 2. Diagram summarizing the key pathophysiological mechanisms linking BPA to T2DM. BPA acts in pleiotropic ways to impact on the main tissues that regulate glucose homeostasis. In the pancreas, it can modulate insulin production positively or negatively to differentially alter the early and late phases of GSIS. BPA affects insulin sensitivity and insulin receptor signalling in the muscle and liver, increases de novo lipogenesis, reduces the release of adiponectin, and alters central feeding behaviour through multiple pathways. GSIS-glucose-stimulated insulin secretion. NPY-neuropeptide Y. POMC-proopiomelanocortin.

\subsubsection{Additional Mechanisms of BPA Action-Beyond Oestrogen Receptors}

Most studies have focused on the physiological responses induced by BPA through its binding to nuclear $E R \alpha / E R \beta$ subtypes. However, BPA exerts endocrine-disrupting effects through several cellular pathways. BPA binds oestrogen-related receptors (ERRs)—orphan nuclear receptors which are closely related to ER $\alpha / \operatorname{ER} \beta$ and that possess constitutive transcriptional activity, potentially impacting on the regulation of common target genes [144]. BPA has also been shown to exert both agonist and antagonist effects on thyroid hormone receptor (TR), and it supresses TR-mediated transcription in a dose-dependent manner. $[145,146]$. BPA competes with $5 \alpha$-dihydrotestosterone for binding to androgen receptor (AR) to exert anti-androgenic effects [147]. BPA modulates the activity of several transcription factors that regulate energy homeostasis and adipogenesis. Primarily, peroxisome proliferator-activated receptors (PPARs) are nuclear receptors with pleiotropic metabolic effects on skeletal muscle, liver, adipocytes, and the gut. Animal and human studies have shown that BPA induces adipocyte and hepatocyte PPAR $\gamma$ expression, leading to fasting hyperglycaemia and glucose intolerance $[90,148]$. Other studies have implicated the CCAAT/enhancer-binding proteins (C/EBPs) family of transcription factors in BPA-induced triglyceride accumulation in human adipose-derived stem cells [149]. BPA has been shown to modulate the synthesis of steroid hormones-including testosterone, androstenedione and oestradiol by reducing the expression of rate-limiting proteins in steroidogenic pathways [150]. Recently, the immunomodulatory effects of BPA were highlighted by studies showing that it diminishes leukocyte telomerase activity and accelerates telomere shortening in CD8+ T cells [151].

An additional mechanism of BPA action involves the modulation of epigenetic mechanisms through changes in DNA methylation, histone modification and changes in microRNA expression. Reviews of BPA-induced epigenetic changes have been provided by several authors $[152,153]$. The transgenerational epigenetic inheritance of changes 
in glucose homeostasis in animal studies induced by BPA through histone modifications affecting PDX1 and insulin-like growth factor 2 (IGF2) expression have been documented [154,155]. BPA alters hepatic glucokinase promoter methylation, further supporting its role in foetal reprogramming and the subsequent development of metabolic disorders in adulthood [156,157].

Clearly, multiple complex cellular pathways are implicated in the modulation of glycaemic responses by BPA, some of which can result in stable heritable epigenetic changes. The integration of these pathways is challenging, as the resulting physiological effects are dose and tissue dependent. Whether the endocrine disrupting effects of different mechanisms of BPA action concur is also debatable.

\subsection{Limitations of Animal Studies}

Several factors need to be taken into consideration when extrapolating animal studies to humans. Primarily, different rodents can exhibit varying tolerances to the effects of EDCs due to underlying variation in genetic factors. For instance, the F344 rat strain is considered to be more sensitive to oestrogen, while Sprague-Dawley and Wistar rats have much lower sensitivity to oestrogen [92]. Secondly, long-term BPA exposure can produce different effects from short-term exposure, possibly due to changes in metabolism and the age of the animal. Furthermore, a specific dose of BPA can elicit distinct effects in different tissues and even between different metabolic pathways in the same organ [92]. The oestrogen receptor-independent effects of BPA outlined above require further assessment in research models. This necessitates the implementation of specific experimental endpoints to appraise their contribution to BPA-induced changes in glucose homeostasis in both animal models and man.

While the route of administration of a particular dose of BPA is typically highly controlled in laboratory experiments, this is not the case in humans. Humans are constantly exposed to small quantities of BPA via many routes, rather than a single dose of BPA via a specific route. Since the largest contribution of BPA in human serum is by oral consumption, this is the preferred route of BPA administration in most animal studies. However, recent works have suggested that subcutaneous BPA administration may produce a ratio of conjugated to unconjugated BPA that closely matches that found in human serum [91]. Additionally, variation in pharmacokinetics between rodents and humans is likely to impact on tissue bioavailability of BPA.

\section{Conclusions}

The extensive body of evidence outlined above provides insight into the multiple mechanisms through which BPA, as a xenoestrogen, modulates physiological pathways linked to the development of T2DM. BPA acts on multiple tissues involved in the regulation of glucose homeostasis. It can positively or negatively modulate pancreatic insulin release and secretion, and alters $\beta$-cell gene expression, electrical activity, and $\beta$-cell survival. This affects adipocytokine function, regulates hepatic and muscle insulin sensitivity, stimulates de novo lipogenesis, and acts on central nervous system pathways regulating feeding and whole-body metabolism. Nevertheless, it must be emphasised that several caveats existprimarily the conflicting findings from population-based research, the comparative lack of prospective follow-up studies and the differences between rodent and human physiology that limit the generalisability of findings. In addition, other residual biases-such as variability in BPA exposure and metabolism between individuals and populations-are difficult to account for in large scale epidemiological investigations. The broad pleiotropic effects of BPA coupled with incongruent outcomes in various studies make a comprehensive description of all these challenging effects. Notwithstanding these factors, important lessons can be derived from existing research that can be used to prioritise EDCs on the global public health agenda. It is equally important for clinicians to be aware of the indirect effects of BPA on human development and chronic disease risk. Common disorders such 
as T2DM have a strong multifactorial aetiology, and this can diminish the effect size of specific variables such as BPA that drive disease development or progression.

Supplementary Materials: The following are available online at https:/ / www.mdpi.com/1660-460 1/18/2/716/s1, Figure S1: PRISMA flow diagram summarising the process of selecting articles to be used in this review.

Author Contributions: All authors contributed equally to this work. All authors have read and agreed to the published version of the manuscript.

Funding: This research received no external funding.

Institutional Review Board Statement: Not applicable.

Informed Consent Statement: Not applicable.

Data Availability Statement: Not applicable.

Conflicts of Interest: The authors declare no conflict of interest.

\section{References}

1. Chatterjee, S.; Khunti, K.; Davies, M.J. Type 2 Diabetes. Lancet 2017, 389, 2239-2251. [CrossRef]

2. Harding, J.L.; Pavkov, M.E.; Magliano, D.J.; Shaw, J.E.; Gregg, E.W. Global Trends in Diabetes Complications: A Review of Current Evidence. Diabetologia 2019, 62, 3-16. [CrossRef]

3. Forbes, J.M.; Cooper, M.E. Mechanisms of Diabetic Complications. Physiol. Rev. 2013, 93, 137-188. [CrossRef] [PubMed]

4. Scheen, A.J. Pathophysiology of Type 2 Diabetes. Acta Clin. Belg. 2003, 58, 335-341. [CrossRef] [PubMed]

5. Barzilai, N.; She, L.; Liu, B.Q.; Vuguin, P.; Cohen, P.; Wang, J.; Rossetti, L. Surgical Removal of Visceral Fat Reverses Hepatic Insulin Resistance. Diabetes 1999, 48, 94-98. [CrossRef]

6. $\quad$ Flannick, J.; Mercader, J.M.; Fuchsberger, C.; Udler, M.S.; Mahajan, A.; Wessel, J.; Teslovich, T.M.; Caulkins, L.; Koesterer, R.; Barajas-Olmos, F.; et al. Exome Sequencing of 20,791 Cases of Type 2 Diabetes and 24,440 Controls. Nature 2019, 570, 71-76. [CrossRef] [PubMed]

7. Silver, M.K.; O'Neill, M.S.; Sowers, M.R.; Park, S.K. Urinary Bisphenol A and Type-2 Diabetes in U.S. Adults: Data from NHANES 2003-2008. PLoS ONE 2011, 6, e26868. [CrossRef]

8. Alonso-Magdalena, P.; Quesada, I.; Nadal, A. Endocrine Disruptors in the Etiology of Type 2 Diabetes Mellitus. Nat. Rev. Endocrinol. 2011, 7, 346-353. [CrossRef]

9. Chailurkit, L.-O.; Tengpraettanakorn, P.; Chanprasertyotin, S.; Ongphiphadhanakul, B. Is Bisphenol A Exposure Associated with the Development of Glucose Intolerance and Increased Insulin Resistance in Thais? Nutr. Health 2017, 23, 185-191. [CrossRef]

10. Rubin, B.S. Bisphenol A: An Endocrine Disruptor with Widespread Exposure and Multiple Effects. J. Steroid Biochem. Mol. Biol. 2011, 127, 27-34. [CrossRef]

11. Andra, S.S.; Kalyvas, H.; Andrianou, X.D.; Charisiadis, P.; Christophi, C.A.; Makris, K.C. Preliminary Evidence of the Association between Monochlorinated Bisphenol A Exposure and Type II Diabetes Mellitus: A Pilot Study. J. Environ. Sci. Health Part A Toxic Hazard Subst. Environ. Eng. 2015, 50, 243-259. [CrossRef] [PubMed]

12. Vandenberg, L.N.; Chahoud, I.; Heindel, J.J.; Padmanabhan, V.; Paumgartten, F.J.R.; Schoenfelder, G. Urinary, Circulating, and Tissue Biomonitoring Studies Indicate Widespread Exposure to Bisphenol A. Environ. Health Perspect. 2010, 118, $1055-1070$. [CrossRef] [PubMed]

13. Song, Y.; Chou, E.L.; Baecker, A.; You, N.-C.Y.; Song, Y.; Sun, Q.; Liu, S. Endocrine-Disrupting Chemicals, Risk of Type 2 Diabetes, and Diabetes-Related Metabolic Traits: A Systematic Review and Meta-Analysis. J. Diabetes 2016, 8, 516-532. [CrossRef] [PubMed]

14. Völkel, W.; Colnot, T.; Csanády, G.A.; Filser, J.G.; Dekant, W. Metabolism and Kinetics of Bisphenol A in Humans at Low Doses Following Oral Administration. Chem. Res. Toxicol. 2002, 15, 1281-1287. [CrossRef]

15. Alonso-Magdalena, P.; Ropero, A.B.; Carrera, M.P.; Cederroth, C.R.; Baquié, M.; Gauthier, B.R.; Nef, S.; Stefani, E.; Nadal, A. Pancreatic Insulin Content Regulation by the Estrogen Receptor ER Alpha. PLoS ONE 2008, 3, e2069. [CrossRef]

16. Soriano, S.; Alonso-Magdalena, P.; García-Arévalo, M.; Novials, A.; Muhammed, S.J.; Salehi, A.; Gustafsson, J.-A.; Quesada, I.; Nadal, A. Rapid Insulinotropic Action of Low Doses of Bisphenol-A on Mouse and Human Islets of Langerhans: Role of Estrogen Receptor $\beta$. PLoS ONE 2012, 7, e31109. [CrossRef]

17. Lee, H.-R.; Kim, T.-H.; Choi, K.-C. Functions and Physiological Roles of Two Types of Estrogen Receptors, ER $\alpha$ and ER $\beta$, Identified by Estrogen Receptor Knockout Mouse. Lab. Anim. Res. 2012, 28, 71-76. [CrossRef]

18. Li, Y.; Burns, K.A.; Arao, Y.; Luh, C.J.; Korach, K.S. Differential Estrogenic Actions of Endocrine-Disrupting Chemicals Bisphenol A, Bisphenol AF, and Zearalenone through Estrogen Receptor $\alpha$ and $\beta$ in Vitro. Environ. Health Perspect. 2012, 120, 1029-1035. [CrossRef]

19. Wetherill, Y.B.; Akingbemi, B.T.; Kanno, J.; McLachlan, J.A.; Nadal, A.; Sonnenschein, C.; Watson, C.S.; Zoeller, R.T.; Belcher, S.M. In Vitro Molecular Mechanisms of Bisphenol A Action. Reprod. Toxicol. 2007, 24, 178-198. [CrossRef]

20. Dong, S.; Terasaka, S.; Kiyama, R. Bisphenol A Induces a Rapid Activation of Erk1/2 through GPR30 in Human Breast Cancer Cells. Environ. Pollut. 2011, 159, 212-218. [CrossRef] 
21. Prossnitz, E.R.; Sklar, L.A.; Oprea, T.I.; Arterburn, J.B. GPR30: A Novel Therapeutic Target in Estrogen-Related Disease. Trends Pharmacol. Sci. 2008, 29, 116-123. [CrossRef] [PubMed]

22. Thomas, P.; Dong, J. Binding and Activation of the Seven-Transmembrane Estrogen Receptor GPR30 by Environmental Estrogens: A Potential Novel Mechanism of Endocrine Disruption. J. Steroid Biochem. Mol. Biol. 2006, 102, 175-179. [CrossRef] [PubMed]

23. Andersson, H.; Brittebo, E. Proangiogenic Effects of Environmentally Relevant Levels of Bisphenol A in Human Primary Endothelial Cells. Arch. Toxicol. 2012, 86, 465-474. [CrossRef] [PubMed]

24. Hugo, E.R.; Brandebourg, T.D.; Woo, J.G.; Loftus, J.; Alexander, J.W.; Ben-Jonathan, N. Bisphenol A at Environmentally Relevant Doses Inhibits Adiponectin Release from Human Adipose Tissue Explants and Adipocytes. Environ. Health Perspect. 2008, 116, 1642-1647. [CrossRef]

25. Okamoto, Y.; Kihara, S.; Ouchi, N.; Nishida, M.; Arita, Y.; Kumada, M.; Ohashi, K.; Sakai, N.; Shimomura, I.; Kobayashi, H.; et al. Adiponectin Reduces Atherosclerosis in Apolipoprotein E-Deficient Mice. Circulation 2002, 106, 2767-2770. [CrossRef]

26. Matsuda, M.; Shimomura, I.; Sata, M.; Arita, Y.; Nishida, M.; Maeda, N.; Kumada, M.; Okamoto, Y.; Nagaretani, H.; Nishizawa, H.; et al. Role of Adiponectin in Preventing Vascular Stenosis. The Missing Link of Adipo-Vascular Axis. J. Biol. Chem. 2002, 277, 37487-37491. [CrossRef]

27. Yamauchi, T.; Kamon, J.; Waki, H.; Terauchi, Y.; Kubota, N.; Hara, K.; Mori, Y.; Ide, T.; Murakami, K.; Tsuboyama-Kasaoka, N.; et al. The Fat-Derived Hormone Adiponectin Reverses Insulin Resistance Associated with Both Lipoatrophy and Obesity. Nat. Med. 2001, 7, 941-946. [CrossRef]

28. Kaser, S.; Tatarczyk, T.; Stadlmayr, A.; Ciardi, C.; Ress, C.; Tschoner, A.; Sandhofer, A.; Paulweber, B.; Ebenbichler, C.F.; Patsch, J.R. Effect of Obesity and Insulin Sensitivity on Adiponectin Isoform Distribution. Eur. J. Clin. Investig. 2008, 38, 827-834. [CrossRef]

29. Cimmino, I.; Oriente, F.; D’Esposito, V.; Liguoro, D.; Liguoro, P.; Ambrosio, M.R.; Cabaro, S.; D'Andrea, F.; Beguinot, F.; Formisano, P.; et al. Low-Dose Bisphenol-A Regulates Inflammatory Cytokines through GPR30 in Mammary Adipose Cells. J. Mol. Endocrinol. 2019, 63, 273-283. [CrossRef]

30. Moher, D.; Liberati, A.; Tetzlaff, J.; Altman, D.G.; PRISMA Group. Preferred Reporting Items for Systematic Reviews and Meta-Analyses: The PRISMA Statement. PLoS Med. 2009, 6, e1000097. [CrossRef]

31. Shu, X.; Tang, S.; Peng, C.; Gao, R.; Yang, S.; Luo, T.; Cheng, Q.; Wang, Y.; Wang, Z.; Zhen, Q.; et al. Bisphenol A Is Not Associated with a 5-Year Incidence of Type 2 Diabetes: A Prospective Nested Case-Control Study. Acta Diabetol. 2018, 55, 369-375. [CrossRef] [PubMed]

32. Soundararajan, A.; Prabu, P.; Mohan, V.; Gibert, Y.; Balasubramanyam, M. Novel Insights of Elevated Systemic Levels of Bisphenol-A (BPA) Linked to Poor Glycemic Control, Accelerated Cellular Senescence and Insulin Resistance in Patients with Type 2 Diabetes. Mol. Cell. Biochem. 2019, 458, 171-183. [CrossRef] [PubMed]

33. Aekplakorn, W.; Chailurkit, L.-O.; Ongphiphadhanakul, B. Association of Serum Bisphenol a with Hypertension in Thai Population. Int. J. Hypertens. 2015, 2015, 594189. [CrossRef] [PubMed]

34. Vandentorren, S.; Zeman, F.; Morin, L.; Sarter, H.; Bidondo, M.-L.; Oleko, A.; Leridon, H. Bisphenol-A and Phthalates Contamination of Urine Samples by Catheters in the Elfe Pilot Study: Implications for Large-Scale Biomonitoring Studies. Environ. Res. 2011, 111, 761-764. [CrossRef]

35. Teeguarden, J.G.; Calafat, A.M.; Ye, X.; Doerge, D.R.; Churchwell, M.I.; Gunawan, R.; Graham, M.K. Twenty-Four Hour Human Urine and Serum Profiles of Bisphenol a during High-Dietary Exposure. Toxicol. Sci. 2011, 123, 48-57. [CrossRef]

36. Sun, Q.; Cornelis, M.C.; Townsend, M.K.; Tobias, D.K.; Eliassen, A.H.; Franke, A.A.; Hauser, R.; Hu, F.B. Association of Urinary Concentrations of Bisphenol A and Phthalate Metabolites with Risk of Type 2 Diabetes: A Prospective Investigation in the Nurses' Health Study (NHS) and NHSII Cohorts. Environ. Health Perspect. 2014, 122, 616-623. [CrossRef]

37. Hwang, S.; Lim, J.-E.; Choi, Y.; Jee, S.H. Bisphenol A Exposure and Type 2 Diabetes Mellitus Risk: A Meta-Analysis. BMC Endocr. Disord. 2018, 18, 81. [CrossRef]

38. Ning, G.; Bi, Y.; Wang, T.; Xu, M.; Xu, Y.; Huang, Y.; Li, M.; Li, X.; Wang, W.; Chen, Y.; et al. Relationship of Urinary Bisphenol A Concentration to Risk for Prevalent Type 2 Diabetes in Chinese Adults: A Cross-Sectional Analysis. Ann. Intern. Med. 2011, 155, 368-374. [CrossRef]

39. Sowlat, M.H.; Lotfi, S.; Yunesian, M.; Ahmadkhaniha, R.; Rastkari, N. The Association between Bisphenol A Exposure and Type-2 Diabetes: A World Systematic Review. Environ. Sci. Pollut. Res. Int. 2016, 23, 21125-21140. [CrossRef]

40. Ahmadkhaniha, R.; Mansouri, M.; Yunesian, M.; Omidfar, K.; Jeddi, M.Z.; Larijani, B.; Mesdaghinia, A.; Rastkari, N. Association of Urinary Bisphenol a Concentration with Type-2 Diabetes Mellitus. J. Environ. Health Sci. Eng. 2014, 12, 64. [CrossRef]

41. Kim, K.; Park, H. Association between Urinary Concentrations of Bisphenol A and Type 2 Diabetes in Korean Adults: A Population-Based Cross-Sectional Study. Int. J. Hyg. Environ. Health 2013, 216, 467-471. [CrossRef] [PubMed]

42. Vandenberg, L.N.; Hauser, R.; Marcus, M.; Olea, N.; Welshons, W.V. Human Exposure to Bisphenol A (BPA). Reprod. Toxicol. 2007, 24, 139-177. [CrossRef] [PubMed]

43. Hill, C.E.; Myers, J.P.; Vandenberg, L.N. Nonmonotonic Dose-Response Curves Occur in Dose Ranges That Are Relevant to Regulatory Decision-Making. Dose Response 2018, 16. [CrossRef] [PubMed]

44. Gore, A.C.; Chappell, V.A.; Fenton, S.E.; Flaws, J.A.; Nadal, A.; Prins, G.S.; Toppari, J.; Zoeller, R.T. Executive Summary to EDC-2: The Endocrine Society's Second Scientific Statement on Endocrine-Disrupting Chemicals. Endocr. Rev. 2015, 36, 593-602. [CrossRef] [PubMed] 
45. Vom Saal Frederick, S. Hughes Claude An Extensive New Literature Concerning Low-Dose Effects of Bisphenol A Shows the Need for a New Risk Assessment. Environ. Health Perspect. 2005, 113, 926-933. [CrossRef] [PubMed]

46. Duan, Y.; Yao, Y.; Wang, B.; Han, L.; Wang, L.; Sun, H.; Chen, L. Association of Urinary Concentrations of Bisphenols with Type 2 Diabetes Mellitus: A Case-Control Study. Environ. Pollut. 2018, 243, 1719-1726. [CrossRef]

47. Watkins, D.J.; Peterson, K.E.; Ferguson, K.K.; Mercado-García, A.; Tamayo y Ortiz, M.; Cantoral, A.; Meeker, J.D.; Téllez-Rojo, M.M. Relating Phthalate and BPA Exposure to Metabolism in Peripubescence: The Role of Exposure Timing, Sex, and Puberty. J. Clin. Endocrinol. Metab. 2016, 101,79-88. [CrossRef]

48. Wang, B.; Li, M.; Zhao, Z.; Lu, J.; Chen, Y.; Xu, Y.; Xu, M.; Wang, W.; Wang, T.; Bi, Y.; et al. Urinary Bisphenol A Concentration and Glucose Homeostasis in Non-Diabetic Adults: A Repeated-Measures, Longitudinal Study. Diabetologia 2019, 62, 1591-1600. [CrossRef]

49. Stahlhut, R.W.; Myers, J.P.; Taylor, J.A.; Nadal, A.; Dyer, J.A.; Vom Saal, F.S. Experimental BPA Exposure and Glucose-Stimulated Insulin Response in Adult Men and Women. J. Endocr. Soc. 2018, 2, 1173-1187. [CrossRef]

50. Welshons, W.V.; Thayer, K.A.; Judy, B.M.; Taylor, J.A.; Curran, E.M.; vom Saal, F.S. Large Effects from Small Exposures. I. Mechanisms for Endocrine-Disrupting Chemicals with Estrogenic Activity. Environ. Health Perspect. 2003, 111, 994-1006. [CrossRef]

51. Nepomnaschy, P.A.; Baird, D.D.; Weinberg, C.R.; Hoppin, J.A.; Longnecker, M.P.; Wilcox, A.J. Within-Person Variability in Urinary Bisphenol A Concentrations: Measurements from Specimens after Long-Term Frozen Storage. Environ. Res. 2009, 109, 734-737. [CrossRef] [PubMed]

52. Teitelbaum, S.L.; Britton, J.A.; Calafat, A.M.; Ye, X.; Silva, M.J.; Reidy, J.A.; Galvez, M.P.; Brenner, B.L.; Wolff, M.S. Temporal Variability in Urinary Concentrations of Phthalate Metabolites, Phytoestrogens and Phenols among Minority Children in the United States. Environ. Res. 2008, 106, 257-269. [CrossRef] [PubMed]

53. Lang, I.A.; Galloway, T.S.; Scarlett, A.; Henley, W.E.; Depledge, M.; Wallace, R.B.; Melzer, D. Association of Urinary Bisphenol A Concentration with Medical Disorders and Laboratory Abnormalities in Adults. JAMA 2008, 300, 1303-1310. [CrossRef] [PubMed]

54. Jacobson, M.H.; Wu, Y.; Liu, M.; Attina, T.M.; Naidu, M.; Karthikraj, R.; Kannan, K.; Warady, B.A.; Furth, S.; Vento, S.; et al. Serially Assessed Bisphenol A and Phthalate Exposure and Association with Kidney Function in Children with Chronic Kidney Disease in the US and Canada: A Longitudinal Cohort Study. PLoS Med. 2020, 17, e1003384. [CrossRef] [PubMed]

55. Ribeiro, E.; Ladeira, C.; Viegas, S. Occupational Exposure to Bisphenol A (BPA): A Reality That Still Needs to Be Unveiled. Toxics 2017, 5, 22. [CrossRef]

56. Stahlhut, R.W.; Welshons, W.V.; Swan, S.H. Bisphenol A Data in NHANES Suggest Longer than Expected Half-Life, Substantial Nonfood Exposure, or Both. Environ. Health Perspect. 2009, 117, 784-789. [CrossRef]

57. Csanády, G.; Oberste-Frielinghaus, H.; Semder, B.; Baur, C.; Schneider, K.; Filser, J. Distribution and Unspecific Protein Binding of the Xenoestrogens Bisphenol A and Daidzein. Arch. Toxicol. 2002, 76, 299-305. [CrossRef]

58. Hormann, A.M.; Vom Saal, F.S.; Nagel, S.C.; Stahlhut, R.W.; Moyer, C.L.; Ellersieck, M.R.; Welshons, W.V.; Toutain, P.-L.; Taylor, J.A. Holding Thermal Receipt Paper and Eating Food after Using Hand Sanitizer Results in High Serum Bioactive and Urine Total Levels of Bisphenol A (BPA). PLoS ONE 2014, 9, e110509. [CrossRef]

59. Gayrard, V.; Lacroix, M.Z.; Collet, S.H.; Viguié, C.; Bousquet-Melou, A.; Toutain, P.-L.; Picard-Hagen, N. High Bioavailability of Bisphenol A from Sublingual Exposure. Environ. Health Perspect. 2013, 121, 951-956. [CrossRef]

60. Welshons, W.V.; Nagel, S.C.; vom Saal, F.S. Large Effects from Small Exposures. III. Endocrine Mechanisms Mediating Effects of Bisphenol A at Levels of Human Exposure. Endocrinology 2006, 147, S56-S69. [CrossRef]

61. Viñas, R.; Goldblum, R.M.; Watson, C.S. Rapid Estrogenic Signaling Activities of the Modified (Chlorinated, Sulfonated, and Glucuronidated) Endocrine Disruptor Bisphenol A. Endocrine Disruptors 2013, 1, e25411. [CrossRef]

62. Ye, X.; Wong, L.-Y.; Jia, L.T.; Needham, L.L.; Calafat, A.M. Stability of the Conjugated Species of Environmental Phenols and Parabens in Human Serum. Environ. Int. 2009, 35, 1160-1163. [CrossRef] [PubMed]

63. Ye, X.; Zhou, X.; Wong, L.-Y.; Calafat, A.M. Concentrations of Bisphenol A and Seven Other Phenols in Pooled Sera from 3-11 Year Old Children: 2001-2002 National Health and Nutrition Examination Survey. Environ. Sci. Technol. 2012, 46, 12664-12671. [CrossRef] [PubMed]

64. Ye, X.; Zhou, X.; Hennings, R.; Kramer, J.; Calafat, A.M. Potential External Contamination with Bisphenol A and Other Ubiquitous Organic Environmental Chemicals during Biomonitoring Analysis: An Elusive Laboratory Challenge. Environ. Health Perspect. 2013, 121, 283-286. [CrossRef]

65. Aguilar, F.; Autrup, H.; Barlow, S.; Castle, L.; Crebelli, R.; Dekant, W.; Toldrá, F. Toxicokinetics of Bisphenol A-Scientific Opinion of the Panel on Food Additives, Flavourings, Processing Aids and Materials in Contact with Food (AFC). EFSA J. 2008, 6, 759. [CrossRef]

66. Churchwell, M.I.; Camacho, L.; Vanlandingham, M.M.; Twaddle, N.C.; Sepehr, E.; Delclos, K.B.; Fisher, J.W.; Doerge, D.R. Comparison of Life-Stage-Dependent Internal Dosimetry for Bisphenol A, Ethinyl Estradiol, a Reference Estrogen, and Endogenous Estradiol to Test an Estrogenic Mode of Action in Sprague Dawley Rats. Toxicol. Sci. 2014, 139, 4-20. [CrossRef]

67. Doerge, D.R.; Twaddle, N.C.; Vanlandingham, M.; Fisher, J.W. Pharmacokinetics of Bisphenol A in Neonatal and Adult SpragueDawley Rats. Toxicol. Appl. Pharmacol. 2010, 247, 158-165. [CrossRef]

68. Vandenberg, L.N.; Gerona, R.R.; Kannan, K.; Taylor, J.A.; van Breemen, R.B.; Dickenson, C.A.; Liao, C.; Yuan, Y.; Newbold, R.R.; Padmanabhan, V.; et al. A Round Robin Approach to the Analysis of Bisphenol a (BPA) in Human Blood Samples. Environ. Health 2014, 13, 25. [CrossRef] 
69. Vom Saal, F.S.; Welshons, W.V. Evidence That Bisphenol A (BPA) Can Be Accurately Measured without Contamination in Human Serum and Urine, and That BPA Causes Numerous Hazards from Multiple Routes of Exposure. Mol. Cell Endocrinol. 2014, 398, 101-113. [CrossRef]

70. Melzer, D.; Rice, N.E.; Lewis, C.; Henley, W.E.; Galloway, T.S. Association of Urinary Bisphenol A Concentration with Heart Disease: Evidence from NHANES 2003/06. PLoS ONE 2010, 5, e8673. [CrossRef] [PubMed]

71. Shankar, A.; Teppala, S. Relationship between Urinary Bisphenol A Levels and Diabetes Mellitus. J. Clin. Endocrinol. Metab. 2011, 96, 3822-3826. [CrossRef] [PubMed]

72. Murphy, L.; Mérida-Ortega, Á.; Cebrián, M.E.; Hernández-Garciadiego, L.; Gómez-Ruiz, H.; Gamboa-Loira, B.; López-Carrillo, L. Exposure to Bisphenol A and Diabetes Risk in Mexican Women. Environ. Sci. Pollut. Res. Int. 2019, 26, 26332-26338. [CrossRef] [PubMed]

73. Sabanayagam, C.; Teppala, S.; Shankar, A. Relationship between Urinary Bisphenol A Levels and Prediabetes among Subjects Free of Diabetes. Acta Diabetol. 2013, 50, 625-631. [CrossRef]

74. Beydoun, H.A.; Khanal, S.; Zonderman, A.B.; Beydoun, M.A. Sex differences in the association of urinary bisphenol-A concentration with selected indices of glucose homeostasis among U.S. adults. Ann Epidemiol. 2014, 24, 90-97. [CrossRef]

75. LaKind, J.S.; Goodman, M.; Naiman, D.Q. Use of NHANES Data to Link Chemical Exposures to Chronic Diseases: A Cautionary Tale. PLoS ONE 2012, 7, e51086. [CrossRef]

76. Russo, G.; Capuozzo, A.; Barbato, F.; Irace, C.; Santamaria, R.; Grumetto, L. Cytotoxicity of Seven Bisphenol Analogues Compared to Bisphenol A and Relationships with Membrane Affinity Data. Chemosphere 2018, 201, 432-440. [CrossRef]

77. Moreman, J.; Lee, O.; Trznadel, M.; David, A.; Kudoh, T.; Tyler, C.R. Acute Toxicity, Teratogenic, and Estrogenic Effects of Bisphenol A and Its Alternative Replacements Bisphenol S, Bisphenol F, and Bisphenol AF in Zebrafish Embryo-Larvae. Environ. Sci. Technol. 2017, 51, 12796-12805. [CrossRef]

78. Chen, D.; Kannan, K.; Tan, H.; Zheng, Z.; Feng, Y.-L.; Wu, Y.; Widelka, M. Bisphenol Analogues Other Than BPA: Environmental Occurrence, Human Exposure, and Toxicity-A Review. Environ. Sci. Technol. 2016, 50, 5438-5453. [CrossRef]

79. Molina-Molina, J.-M.; Amaya, E.; Grimaldi, M.; Sáenz, J.-M.; Real, M.; Fernández, M.F.; Balaguer, P.; Olea, N. In Vitro Study on the Agonistic and Antagonistic Activities of Bisphenol-S and Other Bisphenol-A Congeners and Derivatives via Nuclear Receptors. Toxicol. Appl. Pharmacol. 2013, 272, 127-136. [CrossRef]

80. Ye, X.; Wong, L.-Y.; Kramer, J.; Zhou, X.; Jia, T.; Calafat, A.M. Urinary Concentrations of Bisphenol A and Three Other Bisphenols in Convenience Samples of U.S. Adults during 2000-2014. Environ. Sci. Technol. 2015, 49, 11834-11839. [CrossRef] [PubMed]

81. Rosenfeld, C.S. Neuroendocrine Disruption in Animal Models Due to Exposure to Bisphenol A Analogues. Front. Neuroendocrinol. 2017, 47, 123-133. [CrossRef] [PubMed]

82. Rochester, J.R.; Bolden, A.L. Bisphenol S and F: A Systematic Review and Comparison of the Hormonal Activity of Bisphenol A Substitutes. Environ. Health Perspect. 2015, 123, 643-650. [CrossRef] [PubMed]

83. Park, C.; Song, H.; Choi, J.; Sim, S.; Kojima, H.; Park, J.; Iida, M.; Lee, Y. The Mixture Effects of Bisphenol Derivatives on Estrogen Receptor and Androgen Receptor. Environ. Pollut. 2020, 260, 114036. [CrossRef]

84. Wang, T.; Li, M.; Chen, B.; Xu, M.; Xu, Y.; Huang, Y.; Lu, J.; Chen, Y.; Wang, W.; Li, X.; et al. Urinary Bisphenol A (BPA) Concentration Associates with Obesity and Insulin Resistance. J. Clin. Endocrinol. Metab. 2012, 97, E223-E227. [CrossRef]

85. Casey, M.F.; Neidell, M. Disconcordance in Statistical Models of Bisphenol A and Chronic Disease Outcomes in NHANES 2003-08. PLoS ONE 2013, 8, e79944. [CrossRef]

86. Piecha, R.; Svačina, Š.; Malý, M.; Vrbík, K.; Lacinová, Z.; Haluzík, M.; Pavloušková, J.; Vavrouš, A.; Matějková, D.; Müllerová, D.; et al. Urine Levels of Phthalate Metabolites and Bisphenol A in Relation to Main Metabolic Syndrome Components: Dyslipidemia, Hypertension and Type 2 Diabetes. A Pilot Study. Cent. Eur. J. Public Health 2016, 24, 297-301. [CrossRef]

87. Li, A.J.; Xue, J.; Lin, S.; Al-Malki, A.L.; Al-Ghamdi, M.A.; Kumosani, T.A.; Kannan, K. Urinary Concentrations of Environmental Phenols and Their Association with Type 2 Diabetes in a Population in Jeddah, Saudi Arabia. Environ. Res. 2018, 166, 544-552. [CrossRef]

88. Bi, Y.; Wang, W.; Xu, M.; Wang, T.; Lu, J.; Xu, Y.; Dai, M.; Chen, Y.; Zhang, D.; Sun, W.; et al. Diabetes Genetic Risk Score Modifies Effect of Bisphenol A Exposure on Deterioration in Glucose Metabolism. J. Clin. Endocrinol. Metab. 2016, 101, 143-150. [CrossRef]

89. Rancière, F.; Botton, J.; Slama, R.; Lacroix, M.Z.; Debrauwer, L.; Charles, M.A.; Roussel, R.; Balkau, B.; Magliano, D.J.; D.E.S.I.R. Study Group. Exposure to Bisphenol A and Bisphenol S and Incident Type 2 Diabetes: A Case-Cohort Study in the French Cohort D.E.S.I.R. Environ. Health Perspect. 2019, 127, 107013. [CrossRef]

90. Alonso-Magdalena, P.; Vieira, E.; Soriano, S.; Menes, L.; Burks, D.; Quesada, I.; Nadal, A. Bisphenol A Exposure during Pregnancy Disrupts Glucose Homeostasis in Mothers and Adult Male Offspring. Environ. Health Perspect. 2010, 118, 1243-1250. [CrossRef] [PubMed]

91. Alonso-Magdalena, P.; García-Arévalo, M.; Quesada, I.; Nadal, Á. Bisphenol-A Treatment during Pregnancy in Mice: A New Window of Susceptibility for the Development of Diabetes in Mothers Later in Life. Endocrinology 2015, 156, 1659-1670. [CrossRef] [PubMed]

92. Manukyan, L.; Dunder, L.; Lind, P.M.; Bergsten, P.; Lejonklou, M.H. Developmental Exposure to a Very Low Dose of Bisphenol A Induces Persistent Islet Insulin Hypersecretion in Fischer 344 Rat Offspring. Environ. Res. 2019, 172, 127-136. [CrossRef]

93. Wei, J.; Lin, Y.; Li, Y.; Ying, C.; Chen, J.; Song, L.; Zhou, Z.; Lv, Z.; Xia, W.; Chen, X.; et al. Perinatal Exposure to Bisphenol A at Reference Dose Predisposes Offspring to Metabolic Syndrome in Adult Rats on a High-Fat Diet. Endocrinology 2011, 152, 3049-3061. [CrossRef] [PubMed] 
94. Taylor, J.A.; Sommerfeld-Sager, J.M.; Meng, C.-X.; Nagel, S.C.; Shioda, T.; Vom Saal, F.S. Reduced Body Weight at Weaning Followed by Increased Post-Weaning Growth Rate Interacts with Part-per-Trillion Fetal Serum Concentrations of Bisphenol A (BPA) to Impair Glucose Tolerance in Male Mice. PLoS ONE 2018, 13, e0208846. [CrossRef]

95. Liu, J.; Yu, P.; Qian, W.; Li, Y.; Zhao, J.; Huan, F.; Wang, J.; Xiao, H. Perinatal Bisphenol A Exposure and Adult Glucose Homeostasis: Identifying Critical Windows of Exposure. PLoS ONE 2013, 8, e64143. [CrossRef]

96. Veiga-Lopez, A.; Moeller, J.; Sreedharan, R.; Singer, K.; Lumeng, C.; Ye, W.; Pease, A.; Padmanabhan, V. Developmental Programming: Interaction between Prenatal BPA Exposure and Postnatal Adiposity on Metabolic Variables in Female Sheep. Am. J. Physiol. Endocrinol. Metab. 2016, 310, E238-E247. [CrossRef]

97. Lee, B.-E.; Park, H.; Hong, Y.-C.; Ha, M.; Kim, Y.; Chang, N.; Kim, B.-N.; Kim, Y.J.; Yu, S.-D.; Ha, E.-H. Prenatal Bisphenol A and Birth Outcomes: MOCEH (Mothers and Children's Environmental Health) Study. Int. J. Hyg. Environ. Health 2014, 217, 328-334. [CrossRef]

98. Zhou, Z.; Lei, Y.; Wei, W.; Zhao, Y.; Jiang, Y.; Wang, N.; Li, X.; Chen, X. Association between Prenatal Exposure to Bisphenol a and Birth Outcomes: A Systematic Review with Meta-Analysis. Medicine 2019, 98, e17672. [CrossRef]

99. Giesbrecht, G.F.; Ejaredar, M.; Liu, J.; Thomas, J.; Letourneau, N.; Campbell, T.; Martin, J.W.; Dewey, D. APrON Study Team Prenatal Bisphenol a Exposure and Dysregulation of Infant Hypothalamic-Pituitary-Adrenal Axis Function: Findings from the APrON Cohort Study. Environ. Health 2017, 16, 47. [CrossRef]

100. Miura, R.; Araki, A.; Minatoya, M.; Miyake, K.; Chen, M.-L.; Kobayashi, S.; Miyashita, C.; Yamamoto, J.; Matsumura, T.; Ishizuka, M.; et al. An Epigenome-Wide Analysis of Cord Blood DNA Methylation Reveals Sex-Specific Effect of Exposure to Bisphenol A. Sci. Rep. 2019, 9, 12369. [CrossRef] [PubMed]

101. Sol, C.M.; Santos, S.; Duijts, L.; Asimakopoulos, A.G.; Martinez-Moral, M.-P.; Kannan, K.; Jaddoe, V.W.V.; Trasande, L. Fetal Phthalates and Bisphenols and Childhood Lipid and Glucose Metabolism. A Population-Based Prospective Cohort Study. Environ. Int. 2020, 144, 106063. [CrossRef] [PubMed]

102. Sol, C.M.; Santos, S.; Duijts, L.; Asimakopoulos, A.G.; Martinez-Moral, M.-P.; Kannan, K.; Philips, E.M.; Trasande, L.; Jaddoe, V.W.V. Fetal Exposure to Phthalates and Bisphenols and Childhood General and Organ Fat. A Population-Based Prospective Cohort Study. Int. J. Obes. 2020, 44, 2225-2235. [CrossRef] [PubMed]

103. Bansal, A.; Rashid, C.; Xin, F.; Li, C.; Polyak, E.; Duemler, A.; van der Meer, T.; Stefaniak, M.; Wajid, S.; Doliba, N.; et al. Sexand Dose-Specific Effects of Maternal Bisphenol A Exposure on Pancreatic Islets of First- and Second-Generation Adult Mice Offspring. Environ. Health Perspect. 2017, 125. [CrossRef]

104. Ilagan, Y.; Mamillapalli, R.; Goetz, T.G.; Kayani, J.; Taylor, H.S. Bisphenol-A Exposure in Utero Programs a Sexually Dimorphic Estrogenic State of Hepatic Metabolic Gene Expression. Reprod. Toxicol. 2017, 71, 84-94. [CrossRef]

105. Rubin, B.S.; Paranjpe, M.; DaFonte, T.; Schaeberle, C.; Soto, A.M.; Obin, M.; Greenberg, A.S. Perinatal BPA Exposure Alters Body Weight and Composition in a Dose Specific and Sex Specific Manner: The Addition of Peripubertal Exposure Exacerbates Adverse Effects in Female Mice. Reprod. Toxicol. 2017, 68, 130-144. [CrossRef]

106. Adachi, T.; Yasuda, K.; Mori, C.; Yoshinaga, M.; Aoki, N.; Tsujimoto, G.; Tsuda, K. Promoting Insulin Secretion in Pancreatic Islets by Means of Bisphenol A and Nonylphenol via Intracellular Estrogen Receptors. Food Chem. Toxicol. 2005, 43, 713-719. [CrossRef]

107. Alonso-Magdalena, P.; Morimoto, S.; Ripoll, C.; Fuentes, E.; Nadal, A. The Estrogenic Effect of Bisphenol A Disrupts Pancreatic Beta-Cell Function in Vivo and Induces Insulin Resistance. Environ. Health Perspect. 2006, 114, 106-112. [CrossRef]

108. Batista, T.M.; Alonso-Magdalena, P.; Vieira, E.; Amaral, M.E.C.; Cederroth, C.R.; Nef, S.; Quesada, I.; Carneiro, E.M.; Nadal, A. Short-Term Treatment with Bisphenol-A Leads to Metabolic Abnormalities in Adult Male Mice. PLoS ONE 2012, 7, e33814. [CrossRef]

109. Ruzzin, J.; Petersen, R.; Meugnier, E.; Madsen, L.; Lock, E.-J.; Lillefosse, H.; Ma, T.; Pesenti, S.; Sonne, S.B.; Marstrand, T.T.; et al. Persistent Organic Pollutant Exposure Leads to Insulin Resistance Syndrome. Environ. Health Perspect. 2010, 118, 465-471. [CrossRef]

110. Ding, S.; Fan, Y.; Zhao, N.; Yang, H.; Ye, X.; He, D.; Jin, X.; Liu, J.; Tian, C.; Li, H.; et al. High-Fat Diet Aggravates Glucose Homeostasis Disorder Caused by Chronic Exposure to Bisphenol A. J. Endocrinol. 2014, 221, 167-179. [CrossRef] [PubMed]

111. Marmugi, A.; Lasserre, F.; Beuzelin, D.; Ducheix, S.; Huc, L.; Polizzi, A.; Chetivaux, M.; Pineau, T.; Martin, P.; Guillou, H.; et al. Adverse Effects of Long-Term Exposure to Bisphenol A during Adulthood Leading to Hyperglycaemia and Hypercholesterolemia in Mice. Toxicology 2014, 325, 133-143. [CrossRef] [PubMed]

112. Moon, M.K.; Jeong, I.-K.; Jung Oh, T.; Ahn, H.Y.; Kim, H.H.; Park, Y.J.; Jang, H.C.; Park, K.S. Long-Term Oral Exposure to Bisphenol A Induces Glucose Intolerance and Insulin Resistance. J. Endocrinol. 2015, 226, 35-42. [CrossRef] [PubMed]

113. Laws, S.C.; Carey, S.A.; Ferrell, J.M.; Bodman, G.J.; Cooper, R.L. Estrogenic Activity of Octylphenol, Nonylphenol, Bisphenol A and Methoxychlor in Rats. Toxicol. Sci. 2000, 54, 154-167. [CrossRef] [PubMed]

114. Lin, Y.; Sun, X.; Qiu, L.; Wei, J.; Huang, Q.; Fang, C.; Ye, T.; Kang, M.; Shen, H.; Dong, S. Exposure to Bisphenol A Induces Dysfunction of Insulin Secretion and Apoptosis through the Damage of Mitochondria in Rat Insulinoma (INS-1) Cells. Cell Death Dis. 2013, 4, e460. [CrossRef]

115. Song, L.; Xia, W.; Zhou, Z.; Li, Y.; Lin, Y.; Wei, J.; Wei, Z.; Xu, B.; Shen, J.; Li, W.; et al. Low-Level Phenolic Estrogen Pollutants Impair Islet Morphology and $\beta$-Cell Function in Isolated Rat Islets. J. Endocrinol. 2012, 215, 303-311. [CrossRef]

116. Makaji, E.; Raha, S.; Wade, M.G.; Holloway, A.C. Effect of Environmental Contaminants on Beta Cell Function. Int. J. Toxicol. 2011, 30, 410-418. [CrossRef]

117. Maechler, P.; Wollheim, C.B. Mitochondrial Signals in Glucose-Stimulated Insulin Secretion in the Beta Cell. J. Physiol. 2000, 529, 49-56. [CrossRef] 
118. Westermark, P.; Andersson, A.; Westermark, G.T. Islet Amyloid Polypeptide, Islet Amyloid, and Diabetes Mellitus. Physiol. Rev. 2011, 91, 795-826. [CrossRef]

119. Rushing, P.A.; Hagan, M.M.; Seeley, R.J.; Lutz, T.A.; D’Alessio, D.A.; Air, E.L.; Woods, S.C. Inhibition of Central Amylin Signaling Increases Food Intake and Body Adiposity in Rats. Endocrinology 2001, 142, 5035. [CrossRef]

120. Chapman, I.; Parker, B.; Doran, S.; Feinle-Bisset, C.; Wishart, J.; Lush, C.W.; Chen, K.; Lacerte, C.; Burns, C.; McKay, R.; et al. Low-Dose Pramlintide Reduced Food Intake and Meal Duration in Healthy, Normal-Weight Subjects. Obesity 2007, 15, $1179-1186$. [CrossRef] [PubMed]

121. Brender, J.R.; Salamekh, S.; Ramamoorthy, A. Membrane Disruption and Early Events in the Aggregation of the Diabetes Related Peptide IAPP from a Molecular Prospective. ACC Chem. Res. 2012, 45, 454-462. [CrossRef] [PubMed]

122. Anguiano, M.; Nowak, R.J.; Lansbury, P.T. Protofibrillar Islet Amyloid Polypeptide Permeabilizes Synthetic Vesicles by a Pore-like Mechanism That May Be Relevant to Type II Diabetes. Biochemistry 2002, 41, 11338-11343. [CrossRef] [PubMed]

123. Lorenzo, A.; Razzaboni, B.; Weir, G.C.; Yankner, B.A. Pancreatic Islet Cell Toxicity of Amylin Associated with Type-2 Diabetes Mellitus. Nature 1994, 368, 756-760. [CrossRef] [PubMed]

124. Gong, H.; Zhang, X.; Cheng, B.; Sun, Y.; Li, C.; Li, T.; Zheng, L.; Huang, K. Bisphenol A Accelerates Toxic Amyloid Formation of Human Islet Amyloid Polypeptide: A Possible Link between Bisphenol A Exposure and Type 2 Diabetes. PLoS ONE 2013, 8, e54198. [CrossRef] [PubMed]

125. Sellin, D.; Yan, L.-M.; Kapurniotu, A.; Winter, R. Suppression of IAPP Fibrillation at Anionic Lipid Membranes via IAPP-Derived Amyloid Inhibitors and Insulin. Biophys. Chem. 2010, 150, 73-79. [CrossRef]

126. Höppener, J.W.; Ahrén, B.; Lips, C.J. Islet Amyloid and Type 2 Diabetes Mellitus. N. Engl. J. Med. 2000, 343, 411-419. [CrossRef]

127. Costes, S.; Huang, C.; Gurlo, T.; Daval, M.; Matveyenko, A.V.; Rizza, R.A.; Butler, A.E.; Butler, P.C. $\beta$-Cell Dysfunctional ERAD/Ubiquitin/Proteasome System in Type 2 Diabetes Mediated by Islet Amyloid Polypeptide-Induced UCH-L1 Deficiency. Diabetes 2011, 60, 227-238. [CrossRef]

128. Martinez-Pinna, J.; Marroqui, L.; Hmadcha, A.; Lopez-Beas, J.; Soriano, S.; Villar-Pazos, S.; Alonso-Magdalena, P.; Dos Santos, R.S.; Quesada, I.; Martin, F.; et al. Oestrogen Receptor $\beta$ Mediates the Actions of Bisphenol-A on Ion Channel Expression in Mouse Pancreatic Beta Cells. Diabetologia 2019, 62, 1667-1680. [CrossRef]

129. Kahn, S.E.; Zraika, S.; Utzschneider, K.M.; Hull, R.L. The Beta Cell Lesion in Type 2 Diabetes: There Has to Be a Primary Functional Abnormality. Diabetologia 2009, 52, 1003-1012. [CrossRef]

130. Villar-Pazos, S.; Martinez-Pinna, J.; Castellano-Muñoz, M.; Alonso-Magdalena, P.; Marroqui, L.; Quesada, I.; Gustafsson, J.-A.; Nadal, A. Molecular Mechanisms Involved in the Non-Monotonic Effect of Bisphenol-a on Ca ${ }^{2+}$ Entry in Mouse Pancreatic ß-Cells. Sci. Rep. 2017, 7. [CrossRef] [PubMed]

131. Mackay, H.; Patterson, Z.R.; Khazall, R.; Patel, S.; Tsirlin, D.; Abizaid, A. Organizational Effects of Perinatal Exposure to BisphenolA and Diethylstilbestrol on Arcuate Nucleus Circuitry Controlling Food Intake and Energy Expenditure in Male and Female CD-1 Mice. Endocrinology 2013, 154, 1465-1475. [CrossRef] [PubMed]

132. MacKay, H.; Patterson, Z.R.; Abizaid, A. Perinatal Exposure to Low-Dose Bisphenol-A Disrupts the Structural and Functional Development of the Hypothalamic Feeding Circuitry. Endocrinology 2017, 158, 768-777. [CrossRef] [PubMed]

133. Eckstein, S.S.; Weigert, C.; Lehmann, R. Divergent Roles of IRS (Insulin Receptor Substrate) 1 and 2 in Liver and Skeletal Muscle. Curr. Med. Chem. 2017, 24, 1827-1852. [CrossRef] [PubMed]

134. Karlsson, H.K.R.; Zierath, J.R.; Kane, S.; Krook, A.; Lienhard, G.E.; Wallberg-Henriksson, H. Insulin-Stimulated Phosphorylation of the Akt Substrate AS160 Is Impaired in Skeletal Muscle of Type 2 Diabetic Subjects. Diabetes 2005, 54, 1692-1697. [CrossRef]

135. Perreault, L.; McCurdy, C.; Kerege, A.A.; Houck, J.; Færch, K.; Bergman, B.C. Bisphenol A Impairs Hepatic Glucose Sensing in C57BL/6 Male Mice. PLoS ONE 2013, 8, e69991. [CrossRef]

136. Bindhumol, V.; Chitra, K.C.; Mathur, P.P. Bisphenol A Induces Reactive Oxygen Species Generation in the Liver of Male Rats. Toxicology 2003, 188, 117-124. [CrossRef]

137. Kourouma, A.; Quan, C.; Duan, P.; Qi, S.; Yu, T.; Wang, Y.; Yang, K. Bisphenol A Induces Apoptosis in Liver Cells through Induction of ROS. Available online: https:/ / www.hindawi.com/journals/atox/2015/901983/ (accessed on 4 January 2021).

138. Kim, S.; Mun, G.-I.; Choi, E.; Kim, M.; Jeong, J.S.; Kang, K.W.; Jee, S.; Lim, K.-M.; Lee, Y.-S. Submicromolar Bisphenol A Induces Proliferation and DNA Damage in Human Hepatocyte Cell Lines in Vitro and in Juvenile Rats in Vivo. Food Chem. Toxicol. 2018, 111, 125-132. [CrossRef]

139. Thoene, M.; Rytel, L.; Dzika, E.; Włodarczyk, A.; Kruminis-Kaszkiel, E.; Konrad, P.; Wojtkiewicz, J. Bisphenol A Causes Liver Damage and Selectively Alters the Neurochemical Coding of Intrahepatic Parasympathetic Nerves in Juvenile Porcine Models under Physiological Conditions. Int. J. Mol. Sci. 2017, 18, 2726. [CrossRef]

140. Lin, Y.; Ding, D.; Huang, Q.; Liu, Q.; Lu, H.; Lu, Y.; Chi, Y.; Sun, X.; Ye, G.; Zhu, H.; et al. Downregulation of MiR-192 Causes Hepatic Steatosis and Lipid Accumulation by Inducing SREBF1: Novel Mechanism for Bisphenol A-Triggered Non-Alcoholic Fatty Liver Disease. Biochim. Biophys. Acta (BBA) Mol. Cell Biol. Lipids 2017, 1862, 869-882. [CrossRef]

141. Shimpi, P.C.; More, V.R.; Paranjpe, M.; Donepudi, A.C.; Goodrich, J.M.; Dolinoy, D.C.; Rubin, B.; Slitt, A.L. Hepatic Lipid Accumulation and Nrf2 Expression Following Perinatal and Peripubertal Exposure to Bisphenol A in a Mouse Model of Nonalcoholic Liver Disease. Environ. Health Perspect. 2017, 125, 087005. [CrossRef] [PubMed] 
142. Federico, A.; Dallio, M.; Gravina, A.G.; Diano, N.; Errico, S.; Masarone, M.; Romeo, M.; Tuccillo, C.; Stiuso, P.; Morisco, F.; et al. The Bisphenol A Induced Oxidative Stress in Non-Alcoholic Fatty Liver Disease Male Patients: A Clinical Strategy to Antagonize the Progression of the Disease. Int. J. Environ. Res. Public Health 2020, 17, 3369. [CrossRef] [PubMed]

143. Lin, R.; Wu, D.; Wu, F.-J.; Meng, Y.; Zhang, J.-H.; Wang, X.-G.; Jia, L.-H. Non-Alcoholic Fatty Liver Disease Induced by Perinatal Exposure to Bisphenol a Is Associated With Activated MTOR and TLR4/NF-KB Signaling Pathways in Offspring Rats. Front. Endocrinol. 2019, 10. [CrossRef] [PubMed]

144. Takayanagi, S.; Tokunaga, T.; Liu, X.; Okada, H.; Matsushima, A.; Shimohigashi, Y. Endocrine Disruptor Bisphenol A Strongly Binds to Human Estrogen-Related Receptor Gamma (ERRgamma) with High Constitutive Activity. Toxicol. Lett. 2006, 167, 95-105. [CrossRef]

145. Gorini, F.; Bustaffa, E.; Coi, A.; Iervasi, G.; Bianchi, F. Bisphenols as Environmental Triggers of Thyroid Dysfunction: Clues and Evidence. Int. J. Environ. Res. Public Health 2020, 17, 2654. [CrossRef]

146. Sheng, Z.-G.; Tang, Y.; Liu, Y.-X.; Yuan, Y.; Zhao, B.-Q.; Chao, X.-J.; Zhu, B.-Z. Low Concentrations of Bisphenol a Suppress Thyroid Hormone Receptor Transcription through a Nongenomic Mechanism. Toxicol. Appl. Pharmacol. 2012, 259, 133-142. [CrossRef]

147. Huang, X.; Cang, X.; Liu, J. Molecular Mechanism of Bisphenol A on Androgen Receptor Antagonism. Toxicol. In Vitro 2019, 61, 104621. [CrossRef]

148. Boucher, J.G.; Gagné, R.; Rowan-Carroll, A.; Boudreau, A.; Yauk, C.L.; Atlas, E. Bisphenol A and Bisphenol S Induce Distinct Transcriptional Profiles in Differentiating Human Primary Preadipocytes. PLoS ONE 2016, 11, e0163318. [CrossRef]

149. Salehpour, A.; Shidfar, F.; Hedayati, M.; Neshatbini Tehrani, A.; Farshad, A.A.; Mohammadi, S. Bisphenol A Enhances Adipogenic Signaling Pathways in Human Mesenchymal Stem Cells. Genes Environ. 2020, 42, 13. [CrossRef]

150. Peretz, J.; Flaws, J.A. Bisphenol A Down-Regulates Rate-Limiting Cyp11a1 to Acutely Inhibit Steroidogenesis in Cultured Mouse Antral Follicles. Toxicol. Appl. Pharmacol. 2013, 271, 249-256. [CrossRef]

151. Tran, H.T.T.; Herz, C.; Lamy, E. Long-Term Exposure to “Low-Dose" Bisphenol A Decreases Mitochondrial DNA Copy Number, and Accelerates Telomere Shortening in Human CD8+ T Cells. Sci. Rep. 2020, 10, 15786. [CrossRef] [PubMed]

152. Cimmino, I.; Fiory, F.; Perruolo, G.; Miele, C.; Beguinot, F.; Formisano, P.; Oriente, F. Potential Mechanisms of Bisphenol A (BPA) Contributing to Human Disease. Int. J. Mol. Sci. 2020, 21, 5761. [CrossRef] [PubMed]

153. Mileva, G.; Baker, S.L.; Konkle, A.T.M.; Bielajew, C. Bisphenol-A: Epigenetic Reprogramming and Effects on Reproduction and Behavior. Int. J. Environ. Res. Public Health 2014, 11, 7537-7561. [CrossRef] [PubMed]

154. Chang, H.; Wang, D.; Xia, W.; Pan, X.; Huo, W.; Xu, S.; Li, Y. Epigenetic Disruption and Glucose Homeostasis Changes Following Low-Dose Maternal Bisphenol A Exposure. Toxicol. Res. 2016, 5, 1400-1409. [CrossRef]

155. Mao, Z.; Xia, W.; Chang, H.; Huo, W.; Li, Y.; Xu, S. Paternal BPA Exposure in Early Life Alters Igf2 Epigenetic Status in Sperm and Induces Pancreatic Impairment in Rat Offspring. Toxicol. Lett. 2015, 238, 30-38. [CrossRef]

156. Ma, Y.; Xia, W.; Wang, D.Q.; Wan, Y.J.; Xu, B.; Chen, X.; Li, Y.Y.; Xu, S.Q. Hepatic DNA Methylation Modifications in Early Development of Rats Resulting from Perinatal BPA Exposure Contribute to Insulin Resistance in Adulthood. Diabetologia 2013, 56, 2059-2067. [CrossRef]

157. Li, G.; Chang, H.; Xia, W.; Mao, Z.; Li, Y.; Xu, S. F0 Maternal BPA Exposure Induced Glucose Intolerance of F2 Generation through DNA Methylation Change in Gck. Toxicol. Lett. 2014, 228, 192-199. [CrossRef] 